\title{
Ecosystem Services Evaluation of Nature-Based Solutions with the Help of Citizen Scientists
}

\author{
Francesco Di Grazia ${ }^{1, *}$, Bruna Gumiero ${ }^{2}$, Luisa Galgani ${ }^{1,3,4}{ }^{-}$, Elena Troiani ${ }^{2}$, Michele Ferri ${ }^{5}$ \\ and Steven A. Loiselle $1,3,6 \mathbb{D}$ \\ 1 Department of Biotechnology, Chemistry and Pharmacy, DBCF, University of Siena, Via Aldo Moro 2, \\ 53100 Siena, Italy; lgalgani@fau.edu (L.G.); sloiselle@earthwatch.org.uk (S.A.L.) \\ 2 Department of Biological, Geological and Environmental Sciences, BiGeA, University of Bologna, Via Selmi 3 , \\ 40126 Bologna, Italy; bruna.gumiero@unibo.it (B.G.); elena.troiani@studio.unibo.it (E.T.) \\ 3 CSGI, Center for Colloids and Surface Science, 50019 Sesto Fiorentino, Italy \\ 4 Harbor Branch Oceanographic Institute, Florida Atlantic University, 5600 US-1, Fort Pierce, FL 34946, USA \\ 5 Alto-Adriatico Water Authority / Autorità di Bacino Distrettuale delle Alpi Orientali (AAWA), \\ Cannaregio 4314, 30121 Venice, Italy; michele.ferri@distrettoalpiorientali.it \\ 6 Earthwatch Europe, Mayfield House, 256 Banbury Road, Oxford OX2 7DE, UK \\ * Correspondence: francesco.digrazia@student.unisi.it
}

Citation: Di Grazia, F.; Gumiero, B.;

Galgani, L.; Troiani, E.; Ferri, M.;

Loiselle, S.A. Ecosystem Services

Evaluation of Nature-Based Solutions with the Help of Citizen Scientists.

Sustainability 2021, 13, 10629.

https://doi.org/10.3390/su131910629

Academic Editor: Georgios

Koubouris

Received: 13 August 2021

Accepted: 21 September 2021

Published: 24 September 2021

Publisher's Note: MDPI stays neutral with regard to jurisdictional claims in published maps and institutional affiliations.

Copyright: (c) 2021 by the authors. Licensee MDPI, Basel, Switzerland. This article is an open access article distributed under the terms and conditions of the Creative Commons Attribution (CC BY) license (https:// creativecommons.org/licenses/by/ $4.0 /)$.

\begin{abstract}
Ecosystem services are increasingly being considered in decision-making with respect to mitigating future climate impacts. In this respect, there is a clear need to identify how nature-based solutions (NBS) can benefit specific ecosystem services, in particular within the complex spatial and temporal dynamics that characterize most river catchments. To capture these changes, ecosystem models require spatially explicit data that are often difficult to obtain for model development and validation. Citizen science allows for the participation of trained citizen volunteers in research or regulatory activities, resulting in increased data collection and increased participation of the general public in resource management. Despite the increasing experience in citizen science, these approaches have seldom been used in the modeling of provisioning ecosystem services. In the present study, we examined the temporal and spatial drivers in nutrient delivery in a major Italian river catchment and under different NBS scenarios. Information on climate, land use, soil and river conditions, as well as future climate scenarios, were used to explore future (2050) benefits of NBS on local and catchment scale nutrient loads and nutrient export. We estimate the benefits of a reduction in nitrogen and phosphorus export to the river and the receiving waters (Adriatic Sea) with respect to the costs associated with individual and combined NBS approaches related to river restoration and catchment reforestation.
\end{abstract}

Keywords: ecosystem services; nature-based solutions; citizen science; nutrients export; climate change

\section{Introduction}

Ecosystem services (ESs), identified in relation to the benefits provided to people from ecosystems, are increasingly being considered in decision making by modeling specific services and their geographical context and extent [1-4]. As in any model, the outputs are sensitive to the characteristics of the input data [5]. Often the availability of sufficient data to both develop the model and validate it is a major challenge.

Citizen science (CS) allows for the participation of trained citizen volunteers in research or regulatory activities, often resulting in an increased data collection on spatial and temporal scales [6-9]. CS also facilitates increased participation of the general public in resource management [10-13]. Despite the diffuse experience in ecological and environmental projects [14-16], CS approaches have seldom been used in ES studies focused on provisioning services $[17,18]$, compared to regulating and cultural services [19-21]. Likewise, data from CS have the potential to support reporting SDGs indicators [11,22,23], in particular those related to SDG 6, clean water and sanitation. 
ESs delivered by freshwater ecosystems are strongly influenced by the interaction of land management, catchment hydrology and climate conditions. How this interaction plays out over the complex geological, hydrological and socio-economic conditions of a catchment has direct consequences on ESs related to water quantity and quality [24,25]. Nutrient retention is a key ES, which was modeled using a range of approaches [5,26] that balance the complexity of model accuracy, feasibility, computational cost and applicability. Models that are based on well-tested, relatively simple algorithms using readily available data are more easily understood and adopted by stakeholders [27] to develop more integrated catchment management, fundamental for both river functioning as well as that of its receiving waters. Coastal zones receiving river inputs are experiencing major eutrophication with related environmental and economic damage [28].

Extreme eutrophication in Europe [29-31], North America [32,33] and China [34,35] have had major consequences on local populations and economies. This is particularly important in Europe, where states have invested significantly to achieve good ecological status in water bodies, required by the Water Framework Directive [36] and the Common Agricultural Policy (CAP) [37].

The success of these policies, particularly in Europe [38-40], the United States [41,42] and China [43-45], led to a significant reduction in P load in many rivers and marine waters [46-48]. Because N loading, largely associated with diffuse agricultural sources, was not simultaneously reduced, a significant excess of $\mathrm{N}$ over $\mathrm{P}$ in river loading became the rule, and eutrophication problems persisted in coastal zones. Measures taken to reduce $\mathrm{N}$ losses from agriculture were less effective than those devoted to urban wastewater treatment, both due to the difficulties in tackling diffuse versus point sources of pollution as well as due to agricultural intensification in some areas [46]. However, recent studies integrating agricultural activities for the quantification of diffuse nutrient loading (N especially, and P) and nutrient delivery to the marine coastal zone showed success [49-51].

This led regional and national decision-makers to explore effective and verifiable measures to reduce nutrient loading through NBSs. These efforts are most often focused on improved land use, with particular attention to the riparian interface between terrestrial and aquatic ecosystems, which plays an important role in nutrients and sediments dynamics [52-56]. The riparian forest provides protection against erosion, retention of pollutants, excessive nutrients runoff and water temperature [57-60], with benefits for the quality of human life and biodiversity [61-64]. In this context, Zhang et al. [65] and Yang et al. [66] emphasized the importance of improving our understanding of the benefits of NBS focused on riparian zone restoration.

Besides agricultural intensification, climate change can also enhance eutrophication and its effects on the aquatic environment. Changes in precipitation will modify nutrient delivery through changing surface and river water flows $[67,68]$. These effects are sensitive to precipitation intensity as well as aggregate precipitation as reduced river water flow increases residence time and decreases nutrient dilution [69-71]. Ecosystems' responses to both climate change and eutrophication may be hard to unravel and thus difficult to predict, but current knowledge suggests that climate change will worsen the present situation [28,72].

The present study utilizes multiple data sources and CS to explore the link between NBS and ESs related to nutrient retention. We compare different riparian zone NBS in relation to their ES costs and benefits related to nutrient retention under a future climate change scenario (2050) in one of Italy's most important rivers. 


\section{Materials and Methods}

\subsection{Study Site}

The Piave River, in the northeast of Italy, extends from the Eastern Alps to the Adriatic Sea. It is the fifth-largest Italian river with a watershed of $4127 \mathrm{~km}^{2}$. Approximately 300,000 people live in the catchment, which extends across three Italian regions. The upper catchment (from 500 to $1800 \mathrm{~m}$ a.s.l.) is covered largely by evergreen and deciduous forests (mainly conifers and broad-leaved trees), while alpine pasture/prairies and rock emergence dominate the highest elevations (above $1800 \mathrm{~m}$ a.s.1.) and with limited agricultural activities (Figure 1). Agricultural land use is more prominent in the lower part of the catchment (below $500 \mathrm{~m}$ a.s.l) with an increase in impervious surfaces [73].

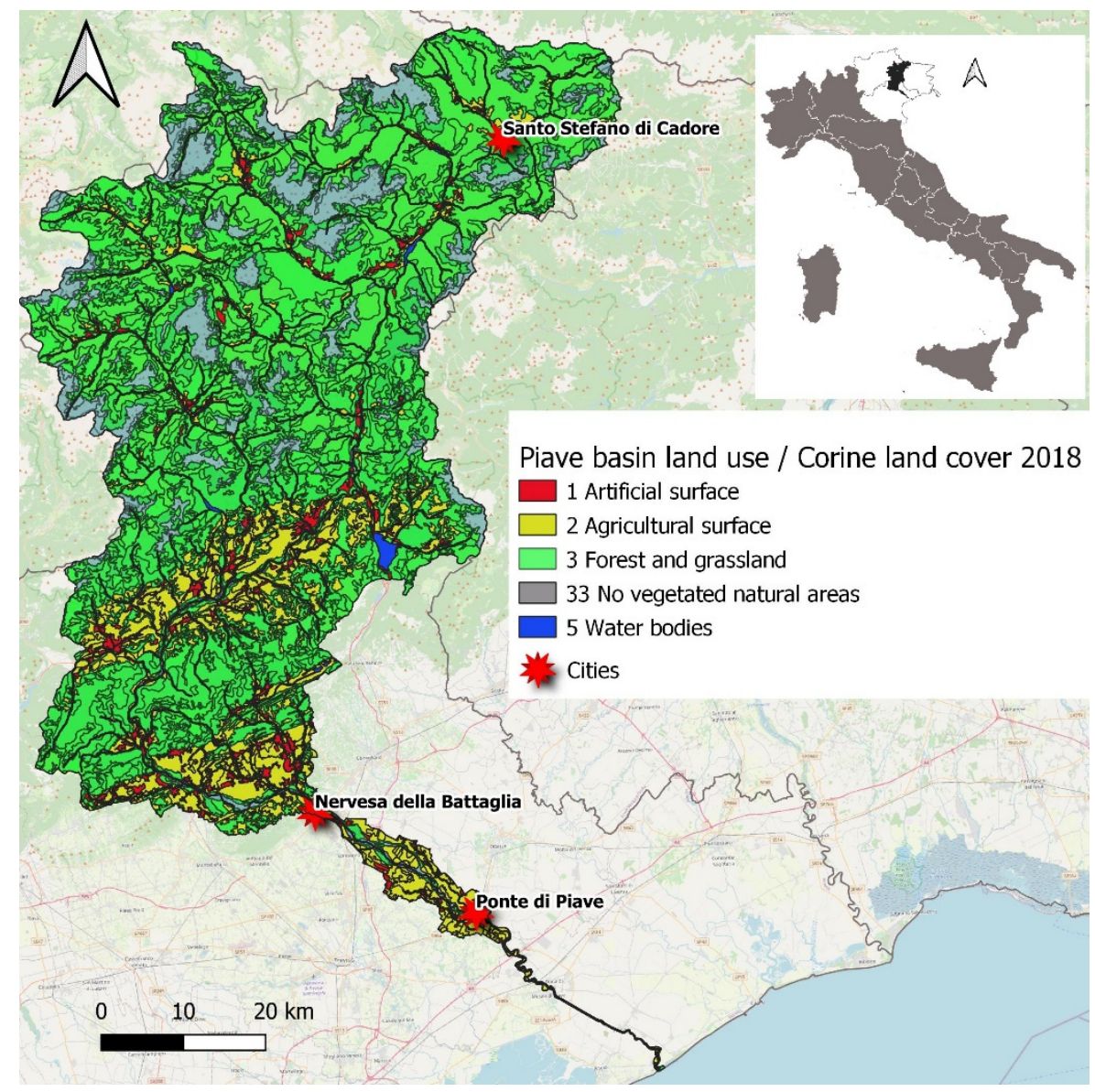

Figure 1. The Piave River catchment and the 2018 Corine land use classes IV level. Class: 1 Artificial surface, 2 Agricultural areas, 3 Forest and grassland, 33 No vegetated natural areas, 5 Water bodies.

\subsection{Model}

Model development and validation were performed using information from different regional, national and global datasets and through in situ monitoring, both from the regional environmental agency (ARPAV) and citizen scientists. Geographic and temporal dynamics of the nutrient export and retention in the Piave River catchment were modeled following the mass balance approach of the InVEST nutrient delivery ratio model (version 3.9) [74]. The model is based on mapping nutrient sources and their potential for transport to the river to identify the spatial variation in nutrient retention across the watershed with respect to different land use/land cover conditions (LULC, e.g., vegetative areas) and catchment morphology.

Catchment nutrients dynamics were based on nutrient loads across the landscape and the nutrient retention capacity of the landscape. Nutrients loads per LULC were identified from data acquired in collaboration with the regional environmental agency, 
river consortiums and available empirical data. Nutrient flows were divided into sedimentbound (transported via surface flow) or dissolved (and transported via subsurface flow). A nutrient delivery ratio index (NDR) was simulated for each pixel (20 m resolution) of the catchment, based on the nutrient loads, LULC, and a digital elevation model. At the watershed outlet, the $\mathrm{P}$ and $\mathrm{N}$ export to the river was calculated based on the weighted aggregation of pixel-level contributions: site-specific information related to the maximum retention efficiency, a runoff proxy (i.e., annual precipitation) representing the spatial variability in runoff potential, and an estimate of the proportion of nutrients delivered via subsurface and surface flows. The subsurface flow was considered for nitrogen only and was estimated from nitrate concentrations in the ground and surface waters.

\subsection{Data Sources for Model Development and Validation}

Data required to develop and validate the nutrient $\mathrm{N}$ and $\mathrm{P}$ models were obtained from multiple sources and include:

- A digital elevation model (DEM), of $20 \mathrm{~m}$ resolution, obtained from the Italian ISPRA (Istituto Superiore per la Protezione e la Ricerca Ambientale) [75], was corrected to fill hydrological sinks and checked with the digital watercourse network to ensure routing along the specific watercourse, using QGIS 3.12 (https:/ / www.qgis.org, accessed on 24 March 2021);

- $\quad$ LULC raster data (2018) were obtained from Corine Land Use Land Cover IV Level for Italy [76], at a $100 \mathrm{~m}$ resolution;

- Nutrient runoff proxies were based on raster precipitation data from 2018, provided by the river catchment authorities (Autorità di Bacino Distrettuale delle Alpi Orientali) at a $20 \mathrm{~m}$ resolution. These raster data were interpolated using an inverse distance weighting of information from 72 stations;

- $\quad$ Future Nutrient runoff proxies were based on precipitation estimates for 2050 by Deszi et al. [77] with high-resolution gridded surfaces at $1 \mathrm{~km}$ cell size developed in an Albers Equal Area Conic projection for Europe. Vector delineation of the watershed was obtained from the geoportal of ARPAV, relative to the Water Protection Plan 2015 (Piano di Tutela delle Acque) [78];

- The threshold value for flow accumulation, the number of upriver cells that flow into a cell before it is considered part of a river, was set to 1000, after several tests to compare the river layer output of the model to the measured river network data [79].

- Borselli's $\mathrm{k}$ for the connection of the surrounding land to the river with respect to the ratio of nutrients reaching the river was set to 2 [80];

- $\quad$ The nutrient ( $\mathrm{N}$ and $\mathrm{P})$ sources associated with each LULC class $\left(\mathrm{kg} \mathrm{ha}^{-1} \mathrm{y}^{-1}\right)$ were based on 2001 data from ARPAV for Corine LULC classes 111-243 (artificial surfaces and agricultural areas) for each municipality and scaled for relative population changes in 2020. For Corine LULC classes 3112-523 (forest and semi-natural areas and water bodies), nutrient load data were obtained from the ARPAV relative to 2018 [81]. The proportion of subsurface $\mathrm{N}$, a floating-point between 0 and 1, was obtained by intersecting a Corine LULC 2018 vector layer with a groundwater infiltration potential layer [82]. In order to obtain the proportion of subsurface $\mathrm{N}$, the groundwater $\mathrm{N}$ infiltration risk potential was compared to the protective soil capacity layer $[83,84]$ (Table 1). For each LULC, the final subsurface_N value is weighted for the \% of Corine LULC polygons per risk class and calculated as the median of all level 1 Corine LULC classes (i.e., all urban classes, all agricultural classes, all forest classes, etc.) (Table 1). 
Table 1. The proportion of subsurface $\mathrm{N}$ weighted for the $\%$ of Corine LULC per risk class.

\begin{tabular}{ccccc}
\hline \multicolumn{2}{c}{ Soil Protective Capacity Table } & $\begin{array}{c}\text { Assigned Risk } \\
\text { Potential }\end{array}$ & $\begin{array}{c}\text { Proportion of } \\
\text { Subsurface_N to Surface } \\
\text { N per Risk Class }\end{array}$ \\
\hline $\begin{array}{c}\text { Protection } \\
\text { Capacity }\end{array}$ & $\begin{array}{c}\text { Infiltration } \\
\text { Flux }\end{array}$ & Loss of NO & Risk & $\begin{array}{c}\text { Reference Values (to Be } \\
\text { Weighted per \% of LULC } \\
\text { Polygons) }\end{array}$ \\
\hline High & $<12 \%$ & $<5 \%$ & Very low & 0.05 \\
\hline Medium high & $12-28 \%$ & $5-10 \%$ & Low & 0.075 \\
\hline Medium low & $29-40 \%$ & $11-20 \%$ & Medium & 0.155 \\
\hline Low & $>40 \%$ & $>20 \%$ & High & 0.2 \\
\hline
\end{tabular}

The proportion of subsurface $\mathrm{N}$ value was estimated using groundwater nitrate data from ARPAV for 2018 [85], which has a lower temporal resolution (30\%) with respect to surface $\mathrm{NO}_{3}$.

- $\quad$ Retention efficiency for $\mathrm{N}$ and $\mathrm{P}$, as the maximum nutrient retention expected from each LULC type, were calculated following Pärn et al. [86], Mayer et al. [87] and Zhang et al. [65];

- $\quad$ Retention lengths for N and P for each LULC class, as the typical distance necessary to reach the maximum retention efficiency, were based on previous studies of riparian buffers [65,87] and ranged from 10 to $300 \mathrm{~m}$. In the absence of data, the retention length was set to the pixel size;

- Subsurface critical length, the distance after which the soil retains $\mathrm{N}$ at its maximum capacity, was set to $200 \mathrm{~m}$ following Mayer et al. [87]. Maximum retention of $\mathrm{N}$ reached through subsurface flow was set to 0.8 [87];

- $\quad$ Nitrate and phosphate concentrations were obtained through regulatory (ARPAV) and CS measurements. Quarterly ARPAV monitoring of total nitrogen and total phosphorus in four stations in the upper catchment and four sites in the lower catchment were used for model development. Data are available online at www.arpa.veneto.it/ dati-ambientali/open-data/idrosfera/corsi-dacqua (accessed on 3 August 2021);

- Trained citizen scientists used the FreshWater Watch method (https: / / freshwaterwatch. thewaterhub.org/content/freshwater-watch-how-guide, accessed on 3 August 2021) to determine nitrate and phosphate in 12 sites in the lower catchment for model validation. Online and video training followed the standard training program of this global citizen science project [88]. Thirty-five participants in the lower catchment of Piave from Ponte di Piave to the sea collected both observation data (color, presence of algae, etc.) and semi-quantitative measurements of water quality (nitrate, phosphate, nephelometric turbidity) $[89,90]$. Nitrate $\left(\mathrm{NO}_{3}-\mathrm{N}\right)$ and phosphate $\left(\mathrm{PO}_{4}-\mathrm{P}\right)$ were measured in closed plastic tubes, which are designed to mix a fixed volume of water with reagents to produce increasing color values (peak absorption at $540 \mathrm{~nm}$ ) with increasing concentration. $\mathrm{PO}_{4}-\mathrm{P}$ concentrations were estimated colourimetrically using inosine enzymatic reactions in seven specific ranges from $0.02 \mathrm{mg} \mathrm{L}^{-1}$ to $1.0 \mathrm{mg} \mathrm{L}^{-1} \mathrm{PO}_{4}-\mathrm{P}(<0.02,0.02-0.05$, $0.05-0.1,0.1-0.2,0.2-0.5,0.5-1.0,<1.0 \mathrm{mg} / \mathrm{L})$ [91]. Nitrate-nitrogen concentrations were estimated colourimetrically using N-(1-napthyl)-ethylenediamine [92], in seven specific ranges from $0.2 \mathrm{mg} \mathrm{L}^{-1}$ to $10 \mathrm{mg} \mathrm{L}^{-1} \mathrm{NO}_{3}-\mathrm{N}(<0.2,0.2-0.5,0.5-1.0,1.0-2.0,2.0-5.0,5-10$, $>10 \mathrm{mg} / \mathrm{L}$ ). The median values for each classification were used to allow for quantitative analysis. During the measurements, geo-location and time were recorded automatically using the FreshWater Watch app and transferred to the online database after validation (https: / / freshwaterwatch.thewaterhub.org/, accessed on 3 august 2021). Once entered, all data underwent quality control by project leaders and citizen scientists.

The complete biophysical table is available in the Supplementary Materials (Table S1). 


\subsection{Climatic Variations}

The potential of NBS to influence ESs is moderated by the local climate conditions, particularly the seasonal and interannual variations in precipitation dynamics. The potential influence of climate change on ES delivery in the present study was explored using historical time series and global climate models.

The climate of the study area has a temperate humid regime with months of maximum precipitation in autumn and late spring (May), with minimum precipitation generally recorded in February and July. The average annual rainfall is highly variable. An analysis of local trends in precipitation and temperature was performed using:

- ARPAV data of Ponte di Piave station (1995-2018) lower catchment, Santo Stefano di Cadore station (1998-2018) upper catchment [93];

- NOAA data (National Oceanographic and Atmospheric Centre, Silver Spring, MD, USA) from NCEP reanalysis (1948-2018) [94];

- Global climate projections (2041-2070) [77].

The climatic components most directly impacting ecosystem services related to the water, carbon and nutrient cycle are the average monthly precipitation, the number of days with precipitation, average monthly temperature and average monthly maximum temperature. The data were subjected to decomposition methods to explore seasonal, inter-annual trends and teleconnections with global climate indices. The North Atlantic Oscillation (NAO) is an important teleconnection scheme influencing European climates. It is based on a dipolar model of mean sea level pressure over the North Atlantic extending from subtropical to sub-arctic latitudes. It is associated with variations in westerly winds relative to Western Europe, an important factor for winter weather in Europe [95,96].

Future projections were developed with the delta method based on multi-model CMIP5 projections for the 2011-2040 and 2041-2070 periods (referred to as the 2020s and 2050s). The baseline reference data for monthly precipitation were constructed with parameter regression of independent slopes model (PRISM) by Daly et al. [97]. We selected a median emission scenario, represented by $(\mathrm{RCP}) 4.5$ that globally predicts a $+1.4{ }^{\circ} \mathrm{C}( \pm 0.5)$ by 2050 .

\subsection{NBS Scenarios}

Corine Land Cover (CLC) was used to conduct the analysis for the current scenario (2018), with a spatial resolution of $100 \mathrm{~m}$ [98]. For the 2050 scenario, three alternative NBS land cover scenarios were developed based on consultations with river authorities and an analysis of photometric and satellite-based images. This analysis showed a consistent and continuous increase in riparian vegetation within the Piave river corridor [99] over the last five decades and a more recent trend in agricultural abandonment in the upper catchment.

Alternative NBS scenarios were generated using QGIS (version 3.12). The first (B1) was based on the reforestation of selected agricultural areas of the upper catchment (conversion of CLC class 243 to class 313). The second (A1) was based on the creation of a riverine hygrophilous forest (class 3116) and an erodible area (class 331) along the river corridor of the lower catchment. The final scenario was the combination of both A1 and B1. River downscaling was performed to highlight better the areas that contribute most to the nutrient delivery to the river. Eight scenario combinations for 2018 and 2050 were explored.

\subsection{Cost Analysis of $N$ and $P$}

In order to compare the costs and benefits of different NBS scenarios, an estimate of the economic value associated with phosphorus and nitrogen retention service of the Piave catchment was determined using the reported costs of recent NBS projects focused on nutrient reduction. The projects considered were performed in the same region by the Drainage Authority 'Consorzio di Bonifica Acque Risorgive', from 2003 to 2020 [100]. These projects were financed by the Decree of the Ministries of the Environment and of Labour to reduce the nutrient loads to the Venice Lagoon. We conducted a multiple linear regression after adjusting for inflation to estimate the typical costs of $\mathrm{N}$ and $\mathrm{P}$ 
removal. These were compared to recent studies on the costs for nitrate and phosphate removal by improvements to wastewater treatment [101,102]. In general, cost estimation of nutrient reduction is based on the analysis and estimation of different components such as energy consumption, chemicals' consumption, personnel salaries, maintenance expenses, construction materials and their quantities, mechanical equipment and land cost $[103,104]$. As NBS actions include costs that are not directly related to individual components, using an empirical aggregated approach was deemed more appropriate.

\section{Results}

The changes in nutrient retention-related ESs in the Piave catchment showed the relative impact of different NBS scenarios and the impact of climate change, in particular precipitation.

\subsection{Climate Change}

In 2018, the highest annual precipitation (mm) occurred in the upper catchment with a mean of $1599 \mathrm{~mm} /$ year, while the precipitation mean in the lower catchment was 1070 $\mathrm{mm} /$ year. The wettest month was October $(396 \mathrm{~mm})$, the month with the least rain was December $(10 \mathrm{~mm})$ (Figure 2).

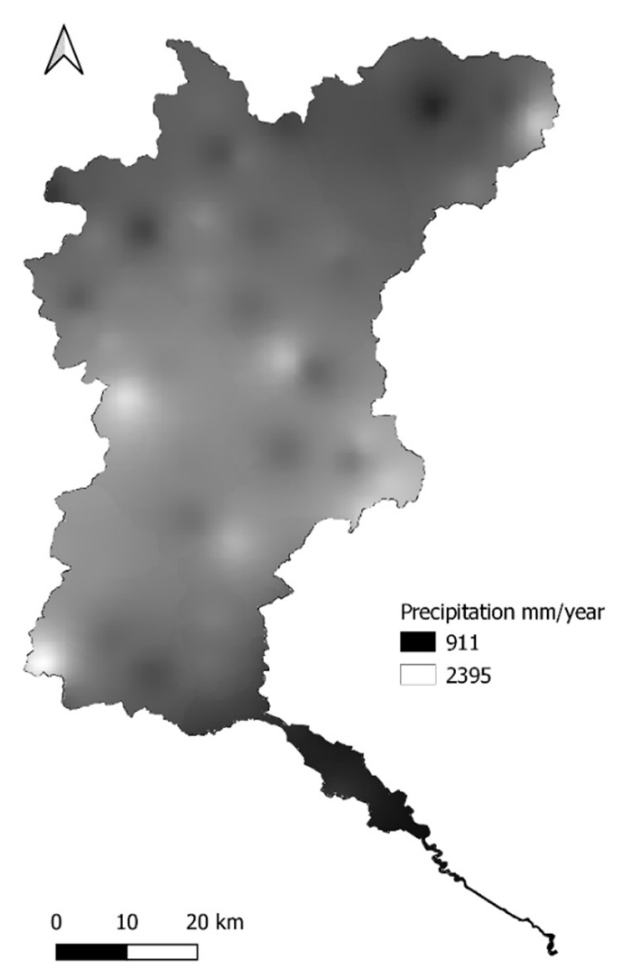

Figure 2. The distribution of precipitation in the Piave River catchment in 2018.

Teleconnections with major climate indices indicated potential links of the catchment climate to conditions in the rest of Europe. The NAO index shows an increased variability since 1950 (Figure 3), associated with the changes in circulation due to differences in pressure at sea level. There were several long periods in which the anomalous circulation of the NAO persisted, particularly from the 1940s to the 1970s, with a downward trend and lower than normal winter temperatures. After a period of relatively negative NAO values, the last 7 years (2012-2018) have seen a significant increase, associated with warmer-thanusual winter temperatures and changes in the precipitation regimes in much of Europe. 


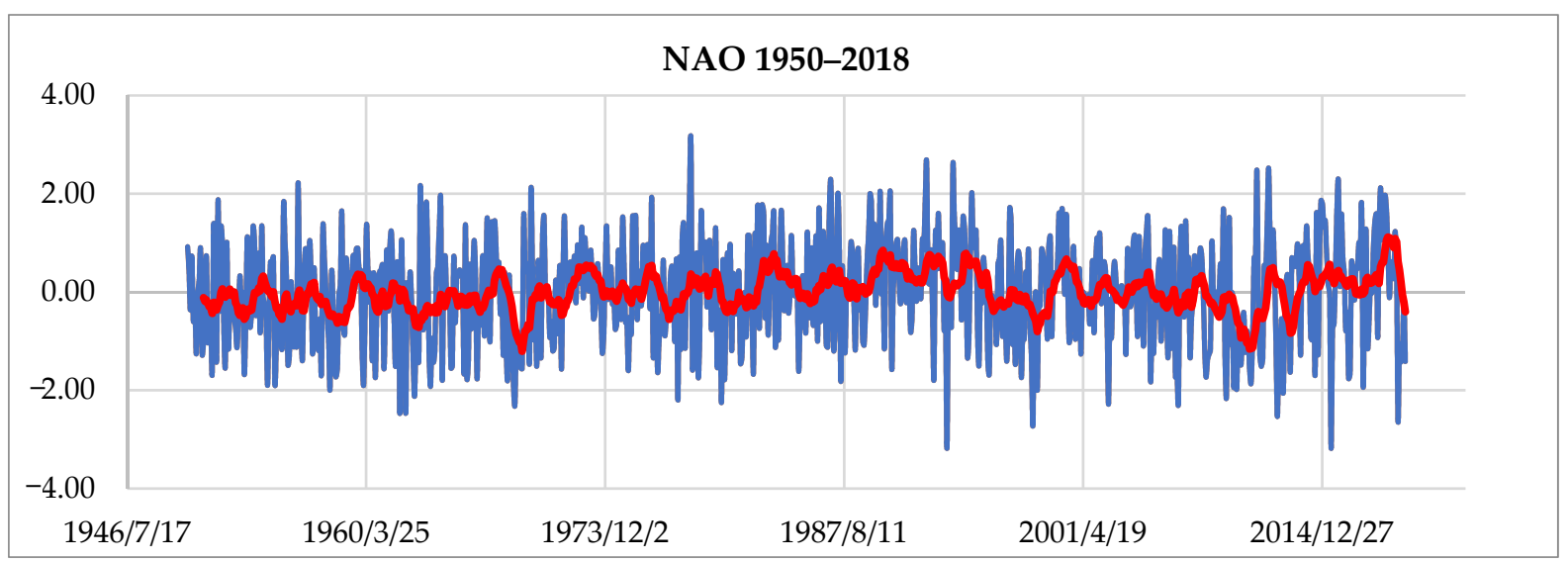

Figure 3. Variability of the NAO indices from 1950 to 2018.

The monthly dynamics of precipitation showed a much lower seasonality with respect to temperature, with the former showing a strong autocorrelation from 1995 to 2018 (Figures 4 and 5).
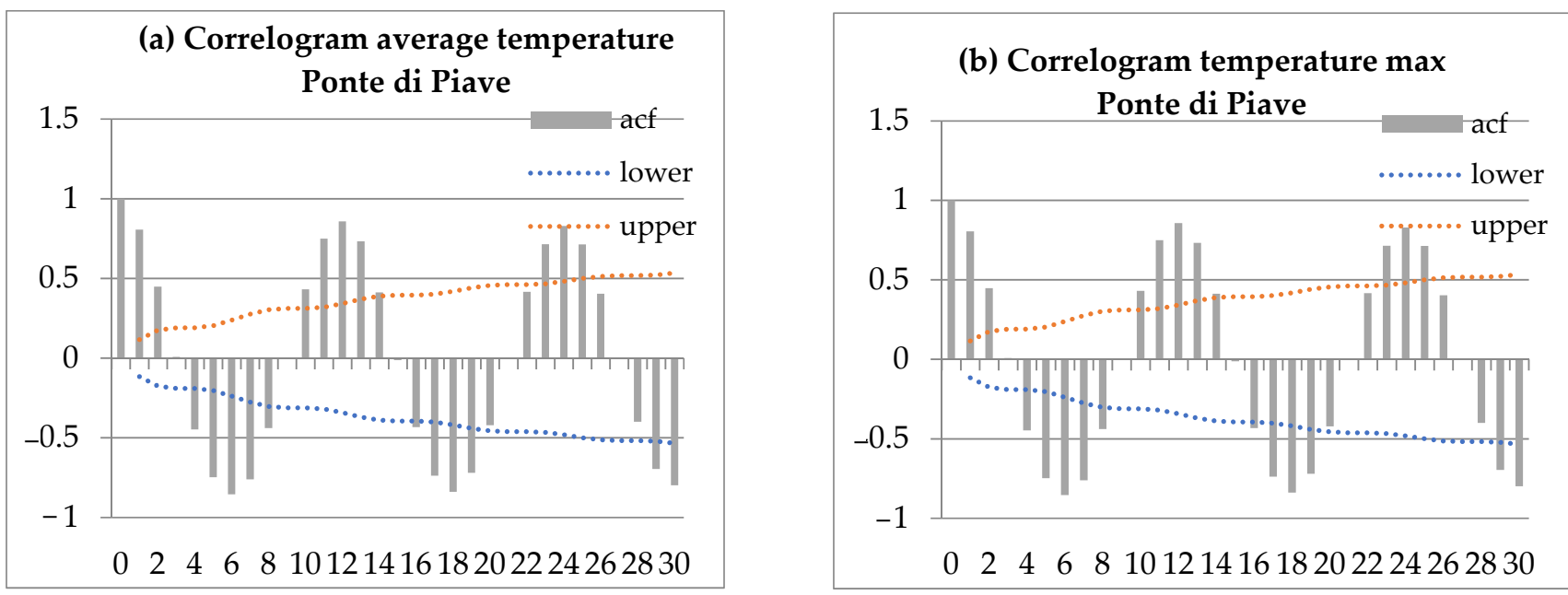

Figure 4. Temperature correlograms $(\mathbf{a}, \mathbf{b})$ showing an elevated seasonal component, indicating the regularity of the monthly average temperature and maximum monthly temperature.

There were no significant interannual trends $(\alpha=0.01)$ identified in the seasonal decomposition for temperature and precipitation. However, there was an increase in the irregular component for temperature $(p<0.001)$, indicating a potential increase of more than $1.5^{\circ} \mathrm{C}$ by 2050 . The increase in the monthly maximum is also significant $(p<0.001)$, characterized by an increase $\left(1.2^{\circ} \mathrm{C}\right.$ by 2050). The irregular component of precipitation (mm and days for months) did not show a clear trend. A clear negative relationship between the monthly NAO indices and precipitation (monthly and precipitation days) was identified. However, the links between the NAO regimes and the hydroclimate are widely regarded as not being constant over time [105]. The output of climate models [106,107] suggests a moderate reduction in expected rainfall in the coming decades. The same models estimate an increase in the temperature of the study area, which implies greater evaporation and a greater hydrological deficit. Current and future trends and variability will have clear impacts on ecosystem services related to nutrient flow within the catchment. 

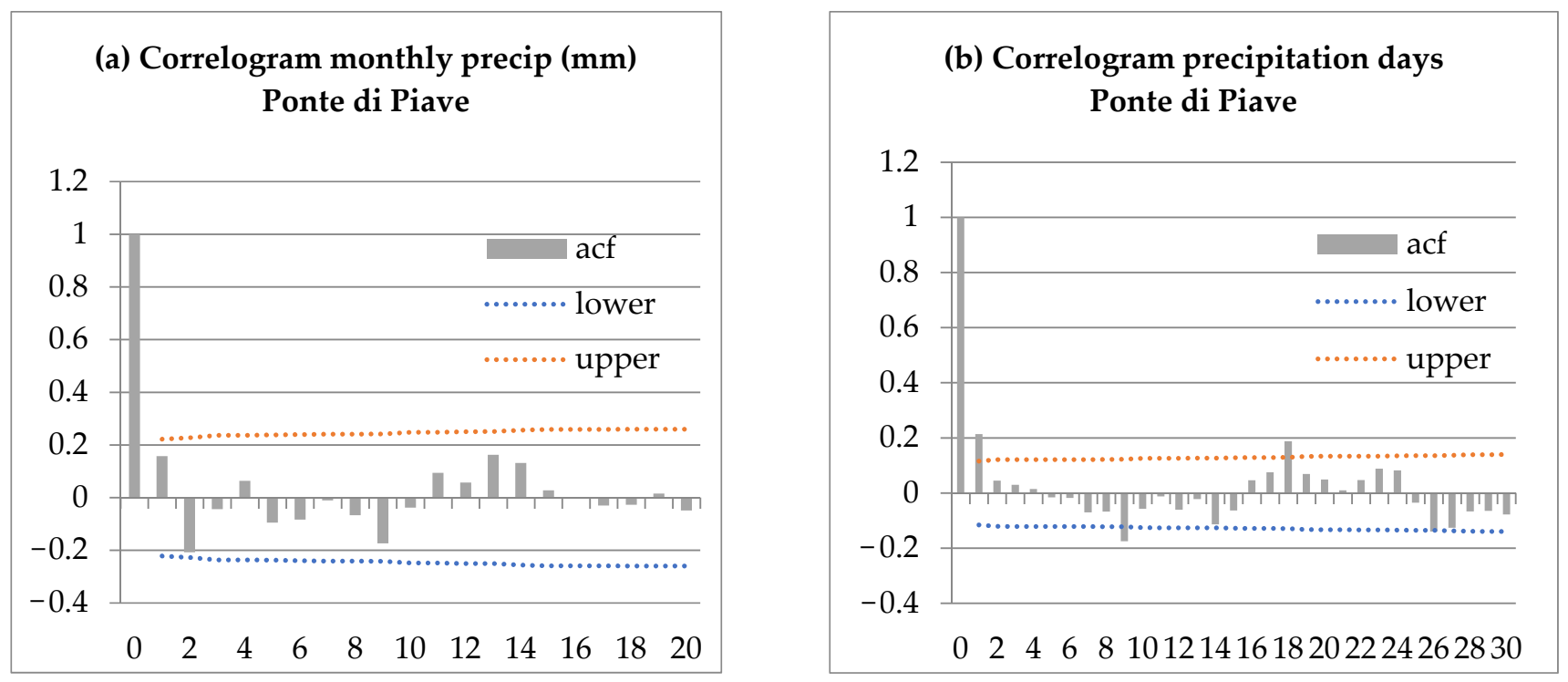

Figure 5. Precipitation correlograms (a,b) showing a high autocorrelation and more complex dynamics.

Future projections represent an ensemble average of 15 Atmosphere-Ocean General Circulation Models of the CMIP5 multi-model data set, corresponding to the IPCC Assessment Report 5 [108]. We selected the median emission scenario RCP 4.5 that globally predicts a $+1.4{ }^{\circ} \mathrm{C}( \pm 0.5)$ by 2050 [77]. This scenario confirmed a decrease in precipitation in 2050, with an estimated minimum of $758 \mathrm{~mm} /$ year and a maximum of $1968 \mathrm{~mm} /$ year (Figure 6).

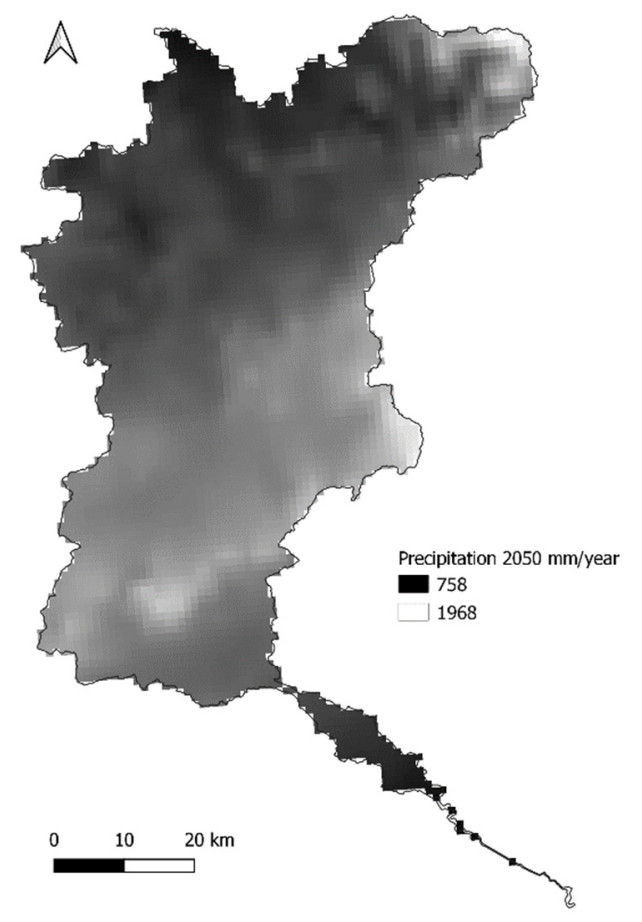

Figure 6. Estimates of yearly annual precipitation in 2050 following IPCC emission scenario RCP 4.5. 


\subsection{Nutrient Export}

In order to validate the modeled $\mathrm{N}$ and $\mathrm{P}$ load exported to the river, the ARPAV and citizen scientist data were used, considering monthly averaged nutrient concentrations and river water flow for 2018 [109]. The monthly averaged flow rate at Ponte di Piave (Table 2) was used, which did not differ significantly from measurements made at Nervesa della Battaglia $\left(130 \mathrm{~m}^{3} / \mathrm{s}\right)$.

Table 2. Piave river flow recorded at Ponte di Piave by flow velocity probe to the year 2018.

\begin{tabular}{ccccc}
\hline Piave Flow $\mathbf{~ m}^{\mathbf{3}} / \mathbf{s}$ & Min & Max & Mean & SD \\
\hline Ponte di Piave & 8.2 & 582.2 & 116 & 184.96 \\
\hline
\end{tabular}

ARPAV samples (Table 3) show high concentrations of total nitrogen (TN) in winter of $2.17 \mathrm{mg} / \mathrm{L}$ and lower concentrations in summer and autumn of $1.32 \mathrm{mg} / \mathrm{L}$. Total phosphorus concentrations (TP) were high in autumn $(0.037 \mathrm{mg} / \mathrm{L})$ and low in winter $(0.021 \mathrm{mg} / \mathrm{L})$.

Table 3. Elaboration of ARPAV data from Ponte di Piave to the year 2018.

\begin{tabular}{cccccc}
\hline ARPAV & Min & Max & Mean & SD & $\begin{array}{c}\text { Export ARPAV } \\
{\left[\text { ton/year }^{-1} \text { ] }\right.}\end{array}$ \\
\hline T-N mg/L & 1.19 & 2.35 & 1.62 & 0.43 & $5.75 \times 10^{3}$ \\
\hline T-P mg/L & 0.016 & 0.059 & 0.029 & 0.01 & $1.04 \times 10^{2}$ \\
\hline
\end{tabular}

Trained citizen scientists collected more than 100 samples along the river in the lower catchment (Table 4), where the number of environmental agency monitoring stations is limited. Nitrate-nitrogen $\left(\mathrm{NO}_{3}-\mathrm{N}\right)$ concentrations were high in autumn $(1.63 \mathrm{mg} / \mathrm{L})$ and low in summer $(0.90 \mathrm{mg} / \mathrm{L})$. Phosphate-phosphorus $\left(\mathrm{PO}_{4}-\mathrm{P}\right)$ concentrations were low in winter $(0.11 \mathrm{mg} / \mathrm{L})$ and high in summer $(0.52 \mathrm{mg} / \mathrm{L})$.

Table 4. Elaboration of Citizen Science data to the year 2020.

\begin{tabular}{cccccc}
\hline CS & Min & Max & Mean & SD & $\begin{array}{c}\text { Export CS } \\
\text { [ton/year }\end{array}$ \\
\hline $\begin{array}{c}\mathrm{NO}_{3}-\mathrm{N} \\
\mathrm{mg} / \mathrm{L}\end{array}$ & 0.1 & 7.5 & 1.37 & 0.61 & $4.48 \times 10^{3}$ \\
\hline $\mathrm{PO}_{4}-\mathrm{P} \mathrm{mg} / \mathrm{L}$ & 0.01 & 1.15 & 0.32 & 0.22 & $8.04 \times 10^{2}$ \\
\hline
\end{tabular}

The NDR model outputs showed a total N and P export of nearly 4500 tons/year of nitrogen and 600 tons of phosphorus (Table 5), with surface loads dominating over subsurface loads.

Table 5. Nutrient Delivery Ratio model results referred to the current scenario (2018).

\begin{tabular}{cccc}
\hline Nutrient NDR Model & $\begin{array}{c}\text { Export_Tot } \\
\text { [ton/year }{ }^{-1} \text { ] }\end{array}$ & $\begin{array}{c}\text { Surface Load } \\
\text { [ton/year }\end{array}$ & $\begin{array}{c}\text { Sub_Surface Load } \\
\text { [ton/year }{ }^{-1} \text { ] }\end{array}$ \\
\hline T-N & $4.47 \times 10^{3}$ & $2.99 \times 10^{4}$ & $5.93 \times 10^{3}$ \\
\hline T-P & $5.96 \times 10^{2}$ & $1.14 \times 10^{4}$ & - \\
\hline
\end{tabular}

By using the precipitation scenario raster for 2050, changes in nutrient export were explored for each scenario of land use, with, without and combined NBS. By applying the same land cover in 2050, $\mathrm{P}$ export is expected to increase by 1.7\% (Table 6). A decrease in the delivery and retention of total $\mathrm{N}$ and total $\mathrm{P}$ reflected the precipitation reduction for the 2050 projection [77]. 
Table 6. NDR model results comparing current (2018) and 2050 estimates of nutrient loads and exports (exp) for the land-use scenarios: A0 B0, without modification into the catchment; A0 B1, with reforestation on the upper catchment; A1 B0, with increased riparian vegetation and erodible bank area in the lower catchment; A1 B1, applying NBS approaches to both the upper and lower catchment.

\begin{tabular}{cccccc}
\hline Year & $\begin{array}{c}\text { Surf_Load_P } \\
\text { [ton/year-1 }\end{array}$ & $\begin{array}{c}\text { Exp_Tot_P } \\
\text { [ton/year }^{-1} \text { ] }\end{array}$ & $\begin{array}{c}\text { Surf_Load_N } \\
\text { [ton/year }^{-1} \text { ] }\end{array}$ & $\begin{array}{c}\text { Sub_Load_N } \\
\text { [ton/year-1] }^{-1}\end{array}$ & $\begin{array}{c}\text { Exp_Tot_N } \\
\text { [ton/year }^{-1} \text { ] }\end{array}$ \\
\hline Current & $1.14 \times 10^{4}$ & $5.96 \times 10^{2}$ & $2.99 \times 10^{4}$ & $5.96 \times 10^{3}$ & $4.47 \times 10^{3}$ \\
\hline 2050 -A0, B0 & $1.13 \times 10^{4}$ & $6.07 \times 10^{2}$ & $2.91 \times 10^{4}$ & $5.83 \times 10^{3}$ & $4.39 \times 10^{3}$ \\
\hline 2050 -A0, B1 & $1.07 \times 10^{4}$ & $4.52 \times 10^{2}$ & $2.87 \times 10^{4}$ & $5.80 \times 10^{3}$ & $4.14 \times 10^{3}$ \\
\hline 2050 -A1, B0 & $1.12 \times 10^{4}$ & $6.04 \times 10^{2}$ & $2.91 \times 10^{4}$ & $5.82 \times 10^{3}$ & $4.39 \times 10^{3}$ \\
\hline 2050 -A1, B1 & $1.07 \times 10^{4}$ & $4.48 \times 10^{2}$ & $2.86 \times 10^{4}$ & $5.80 \times 10^{3}$ & $4.13 \times 10^{3}$ \\
\hline
\end{tabular}

The reforestation scenario (B1) provided a reduction both for $\mathrm{N}$ and $\mathrm{P}$ load and export (Table 6). P export decreased by $24 \%$, corresponding to a reduction of 144 tons/year. The $\mathrm{N}$ export reduction was relatively lower (7\%), with a reduction of 328 tons/year. The reforestation scenario was based on the conversion of CLC class 243 (Agriculture with natural vegetation) to class 313 (Mixed Forest) (11,549 ha) and 3116 (Hygrophilous Forest) (3025 ha) (Figure 7a), resulting in an increase of $5 \%$ in forest cover in the upper catchment

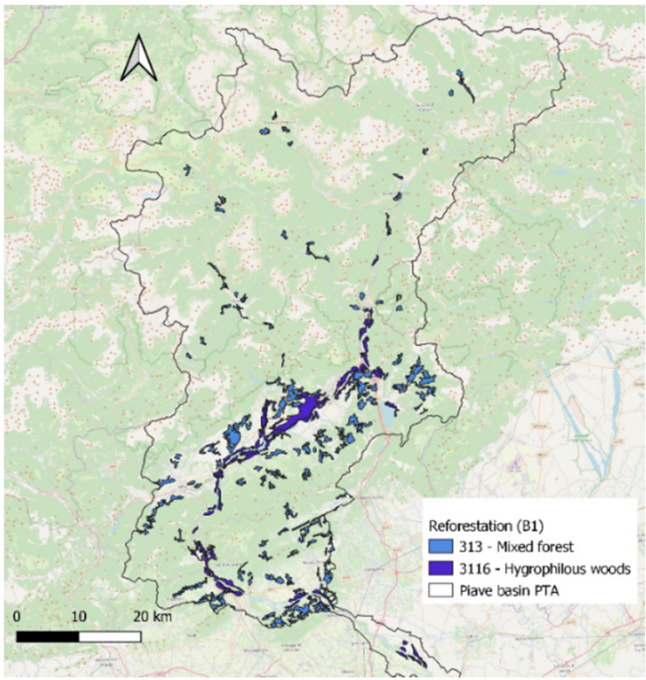

(a)

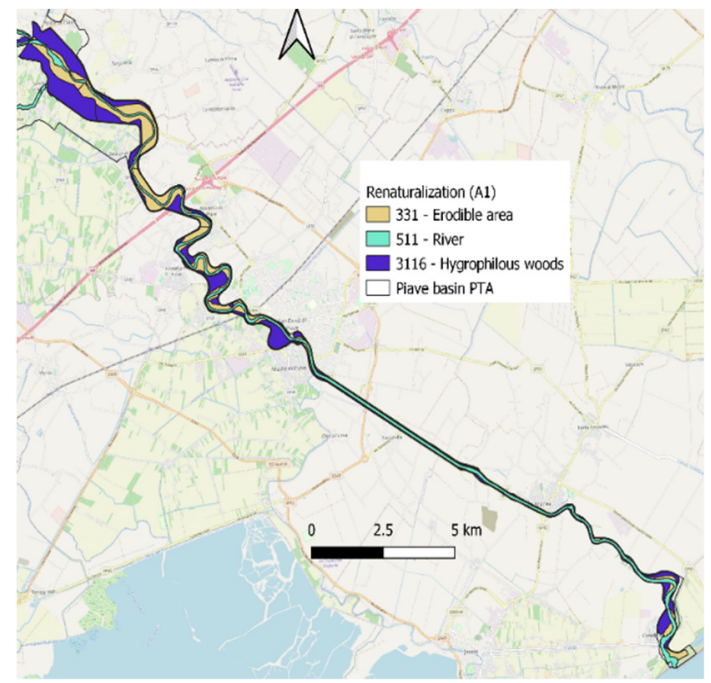

(b)

Figure 7. (a) B1 Land cover scenario, the polygons are the areas with reforestation (313) mixed forest and (3116) hygrophilous forest in the upper catchment. (b) A1 Land cover scenario with riverine hygrophilous forest (class 3116) and erodible area (class 331) of the lower catchment section from Ponte di Piave to the sea.

For the lower catchment riverine corridor scenario (A1), there was an estimated increase in the $\mathrm{P}$ export by $1.3 \%$ due to the increment of sand and gravel where the $\mathrm{P}$ is more linked. $\mathrm{N}$ export decreased by $1.8 \%$, or 80 tons/year (Figure 8 ). This scenario was based on an increase in the hygrophilous forest along the lower catchment river corridor from $6.54 \%$ to $34.87 \%$ (class 3116 area $650 \mathrm{ha}$ ) and the erodible area between the river banks (class 331 area 420 ha) (Figure 7b). 


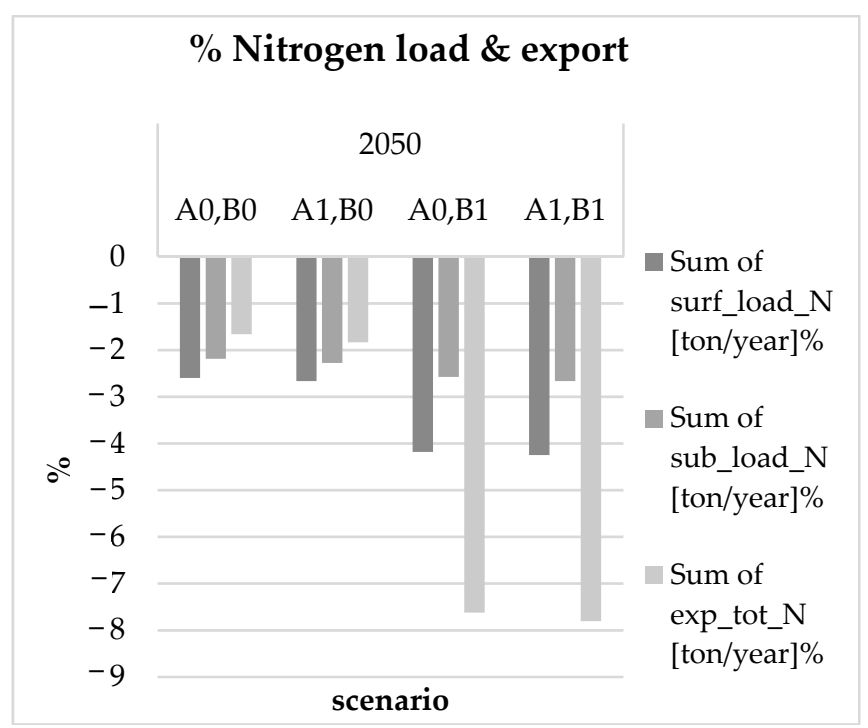

(a)

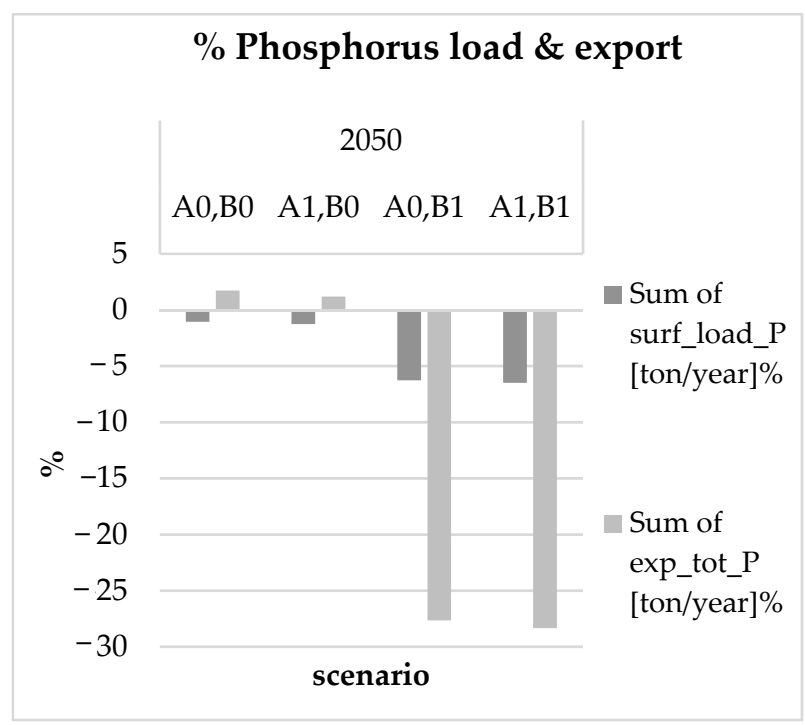

(b)

Figure 8. The percentage reduction in N (a) and P (b) load and export in 2050 between different NBS scenarios.

When both NBS scenarios were considered (A1, B1), there was a decrease in both export and load for both nutrients (Figure 8 ). N export decreased by nearly $8 \%$, or 340 tons/year, while P export decreased by $25 \%, 148$ tons/year (Figure 8 ).

\section{Discussion}

\subsection{Nutrient Dynamics and Distribution}

There is growing awareness that NBS can help to reduce climate change-related impacts as well as providing ecosystem services [110,111]. The results of the simulated nutrient conditions in four different NBS scenarios for 2050 suggest that the nutrient load and export in the Piave river catchment is sensitive to climate change and to an increase in wooded areas, particularly in agricultural areas where there is a trend in agricultural land abandonment $[112,113]$. This rural exodus, which began after World War II, triggered the process of natural vegetation regrowth that continues into the present [114]. Reforestation presents multiple benefits, promoting biodiversity [115] as well as reducing surface water runoff and soil erosion [116], control sediment loss and improve soil properties [117].

The overall impact of each NBS scenario is clear in the reduced export of both phosphorus and nitrogen, with the largest reduction for a single scenario occurring for B1, the reforested area of the upper catchment (export reduction for $\mathrm{N}$ of 328 tons/year, export reduction for $\mathrm{P}$ of 144 tons/year). The values confirm support studies that show increased forest cover and decreased agricultural areas decrease sediment, nitrogen and phosphorus exports [55].

The reductions associated with the scenario of $\mathrm{A} 1$ in the lower section are less evident but still represent a significant reduction in nutrient export. The lower catchment is heavily impacted by intensive agriculture both inside and outside the river banks, leaving very little area for hygrophilous riparian vegetation, with that remaining colonized often by invasive species. NBS actions focused on river renaturalization and restoration were shown to provide multiple benefits on nutrient mitigation as well as other ES. The erodible bank expansion in the A1 scenario is also intended to restore river dynamics but, as a consequence, will increase P export [118].

While the overall reductions in nutrient export provide a tool for understanding the benefits of NBS related reforestation and restoration activities, key information can be gained from exploring the spatial distribution of ecosystem services based on different scenarios. By using spatially explicit models, it was possible to identify the locations within the catchment with the greatest sensitivity to climate change and NBS actions, in this case with respect to nutrient loads and nutrient export. As expected, the areas closest to the 
river network have the highest nutrient export in relation to their retention capacity of the vegetation downslope, substrate and drainage.

The difference between current and 2050 A1B1 scenarios shows that areas closest to the river have the largest potential for a reduction in P export (Figure 9). Changes in $\mathrm{N}$ export (Figure 10) were less spatially distinct as nitrate is more mobile [110]. Complete 2050 scenario maps are available in the Supplementary Materials (Figures S1 and S2).

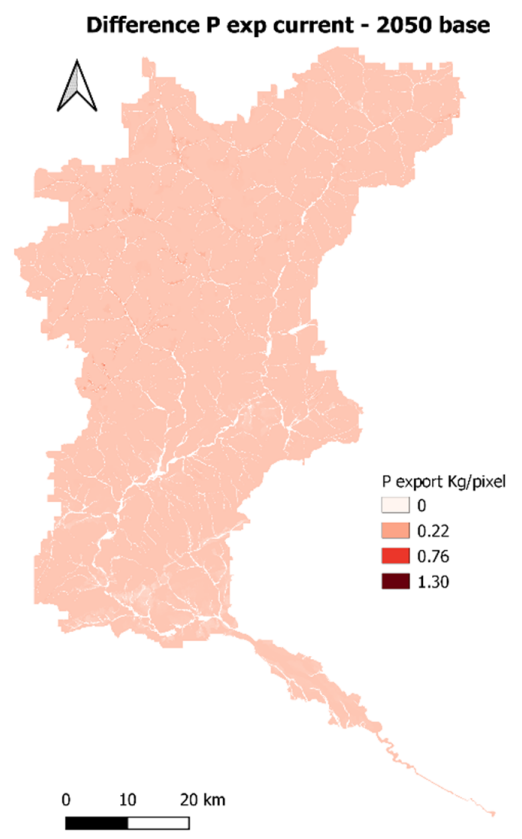

(a)

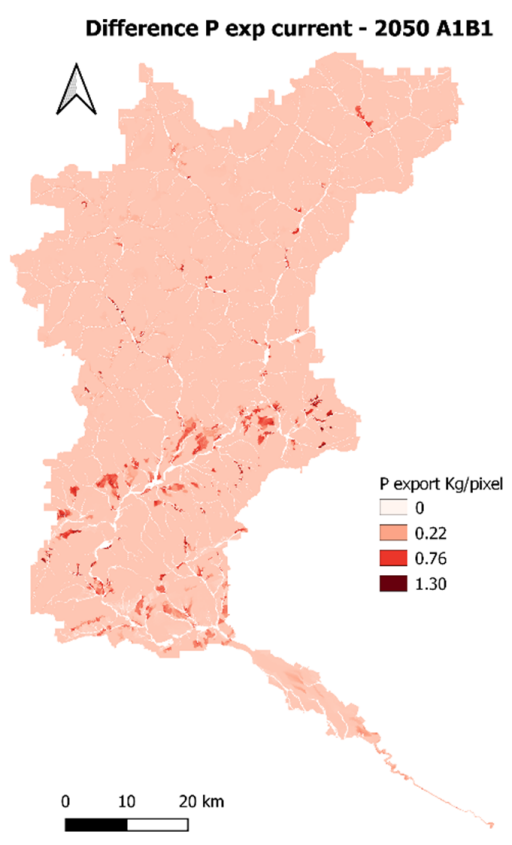

(b)

Figure 9. Spatial distribution in the change (reduction) in phosphorus (P) export between 2018 A0B0 and 2050 for scenarios A0B0 (a) and A1B1 (b).

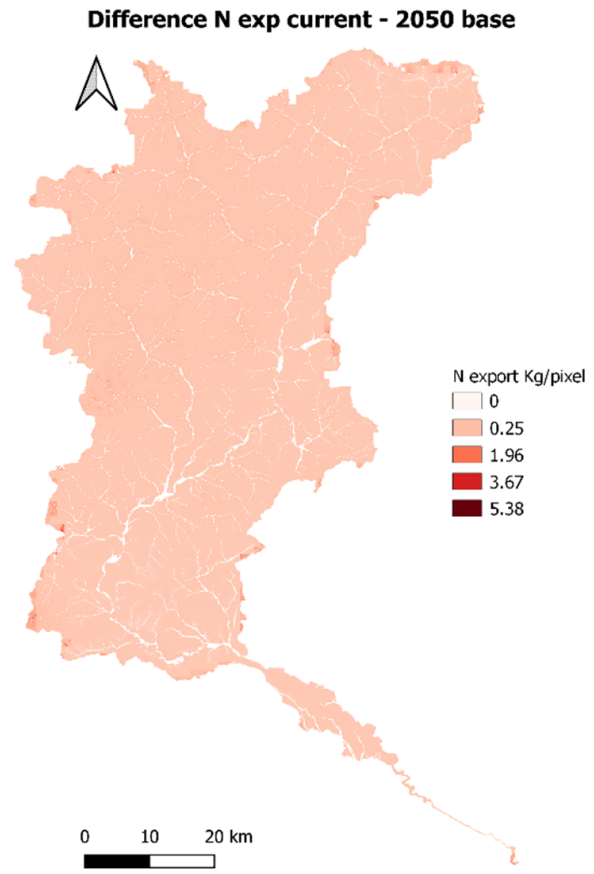

(a)

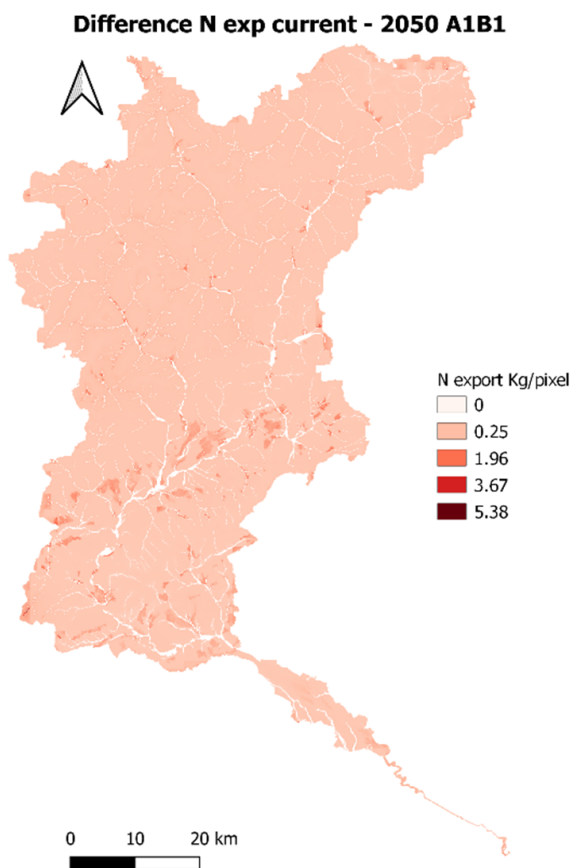

(b)

Figure 10. Spatial distribution in the change (reduction) in nitrogen (N) export between 2018 A0B0 and 2050 for scenarios A0B0 (a) and A1B1 (b). 


\subsection{ESs Evaluation of NBS}

The selection of the best single or combined NBS depends on the relative value associated with each ecosystem service and the increase or decrease in that service provider. By considering only nutrient reduction, it is possible to compare the impact of each scenario and considering overall changes in main drivers related to climate and land use. The results based on the simulated nutrient load and delivery under four different NBS scenarios, $\mathrm{A} 0 \mathrm{~B} 0, \mathrm{~A} 1 \mathrm{~B} 0, \mathrm{~A} 0 \mathrm{~B} 1$ and A1B1, show significant differences. There is a clear potential for a reduction in nitrogen export in 2050 for all scenarios. This was associated with reduced expected precipitation of $1363 \mathrm{~mm}$ /year compared to $1653 \mathrm{~mm}$ /year in 2018, particularly in the elevated alpine parts of the catchment. In fact, the largest reduction in nitrogen export was achieved by reforestation of the upper catchment (B1). This NBS alone provides a potential reduction of 328 tons/year. The costs of natural reforestation are limited, and the benefits to lower catchment and receiving waters (Adriatic Sea) could be translated to support for farmers to manage these lands as productive forests. It is expected that the new European agricultural policy will incentivize this transformation of land use. On the other hand, N and P loads from urban wastewater represent a significant source [119]. Recent studies on lowland rivers that have created riparian buffer strips have shown an elevated efficiency to remove nitrate [56].

The overall best scenario is the combination of NBS approaches in both the lower and upper parts of the river. Under the A1B1 scenario, nitrogen export was reduced by 340 tons/year in 2050.

Efforts to reduce phosphorus export are complicated by an expected increase in rainfall intensity in 2050 in relation to the soil characteristics of the Piave river catchment. This increased export is partially mitigated by the A1 and completely reversed in the B1 scenarios. The best scenario is the A1B1 scenario which showed a 148 ton/year reduction in phosphorus export.

To properly estimate the benefits of the proposed NBS, the impacts on other ecosystem services should be considered. Several of these (flood risk reduction, carbon storage and water yield) may be highly significant. However, to explore only those associated with nutrient reduction, we used costs associated with similar NBS projects focused on nutrient reduction to the Venice Lagoon [100]. These projects (Table 7) had a range of secondary benefits that were not evaluated in the present analysis. The estimated costs for the associated reduction for nitrogen and for phosphorus were calculated using a multiple linear regression analysis $\left(R^{2}=0.79, p<0.001\right)$.

Table 7. The cost of individual NBS projects and the associated annual reduction in $\mathrm{N}$ and $\mathrm{P}$ in the Veneto region.

\begin{tabular}{ccc}
\hline Euro & N Tot Ton/Year & P Tot Ton/Year \\
\hline $7,230,000 €$ & 44.9 & 3.2 \\
$4,130,000 €$ & 27.4 & 1.47 \\
$6,600,000 €$ & 43.49 & 1.4 \\
$3,160,000 €$ & 4.9 & 0.5 \\
$825,000 €$ & 1.066 & 0.45 \\
$1,560,000 €$ & 2.14 & 0.50 \\
$2,450,000 €$ & 5.8 & 0.66 \\
$1,650,000 €$ & 4.31 & 0.66 \\
$1,440,000 €$ & 2.56 & 0.22 \\
$1,000,000 €$ & 1.08 & 0.28 \\
$2,066,000 €$ & 18 & 0.81 \\
$1,033,000 €$ & 13.94 & 1.56 \\
$3,430,000 €$ & 5.02 & 1.08 \\
\hline
\end{tabular}


With an expected intervention cost of EUR 1,128,836 (y-intercept), the cost per ton of $\mathrm{N}$ removed by NBS amount was $10.88 \mathrm{EUR} / \mathrm{kgN}$ per year. The estimated cost for $\mathrm{P}$ was approximately double or $23.83 \mathrm{EUR} / \mathrm{kgP}$ per year. These compare well to estimated costs from wastewater treatment upgrades reported by Gratziou and Chrisochoidou [104], who estimated that for nitrogen removal, the cost of a project varies from $4613 \mathrm{EUR} / \mathrm{m}^{3}$ to $488 \mathrm{EUR} / \mathrm{m}^{3}$, with total annual operation cost ranges from $204 \mathrm{EUR} / \mathrm{m}^{3}$ to $17 \mathrm{EUR} / \mathrm{m}^{3}$. The unit cost for $\mathrm{P}$ removal in different treatment alternatives ranges from $80 \mathrm{EUR} / \mathrm{kgP}$ to 120 EUR/kgP (Bashar et al., 2018). Jabłonska et al. [120] estimated the costs of a hypothetical establishment of wetland buffer zones to reduce the non-point source of $\mathrm{N}$ and $\mathrm{P}$ to be EUR $9 \pm 107 \mathrm{M}$ to remove $11 \%-82 \% \mathrm{~N}$ and $14 \%-87 \% \mathrm{P}$ load from the catchment. This translates into a cost that is saved due to the lack of eutrophication and the problems associated with it [121].

Considering the annual reduction in nitrogen and phosphorus exports achieved using NBS (A1 and B1), compared to scenarios with no NBS (A0, B0), the value of these interventions per year is equal to EUR 2,244,677 for A1 and EUR 2,610,888 for B1, using 2018 values. Given the long-term benefits and multiple risks of climate change, as well as the important secondary benefits, the NBS solutions are well justified.

\section{Conclusions}

There is growing awareness that NBS can mitigate climate change impacts while securing ESs. The results from the present study, estimating nutrient load and delivery under four different NBS scenarios, suggest that the nutrient load and delivery in the Piave river catchment would benefit from NBS actions, one of which is already underway through rural abandonment. Upper catchment reforestation has increased wooded areas in agricultural lands that are no longer used by local farmers. Reduced water runoff and sediment loss have had and will continue to have positive impacts on sediment, nitrogen and phosphorus loads to the river.

The proposed NBS for the lower catchment $(32 \mathrm{~km})$ riverine corridor, based on increased riparian vegetation and erodible areas (A1), will have a more complex activation due to the intense agricultural and urban use that characterizes this part of the catchment. An increase in vegetated areas in the riparian area will reduce the transport of phosphorusloaded particulates from agricultural soils as a result of erosion. While A1 has a smaller effect on overall nutrient export with respect to B1, this NBS is likely to have more impacts on other major ecosystem services related to biodiversity and recreational value due to the more elevated population density. Decreasing trends in P export by rivers in Europe have mainly resulted from environmental and agricultural policies leading to reduced nutrient inputs to river catchments. On the other hand, nitrate remains a major challenge in many catchments and already compromised receiving waters, such as the Adriatic Sea. The IPCC Climate Change and Land Report [122] emphasizes the need to explore the mitigation potential of restoration actions and the improved management of forests.

It is clear that increased participation in the management and monitoring of our river environments is necessary to improve their status further. Citizen science represented an additional tool to complete the information and for model validation in this study and others. Involving citizen participants directly in monitoring activities can generate a powerful tool to complete the lack of information and improves communities' influence on management policy in their territory. Understanding the direct and indirect influence of human activities is the first step to evaluate the economic value of nutrients removal. Our estimated cost reflects the gains from investing in NBS and shows how the evaluation of ecosystem services can provide a complete evaluation of where and how watersheds can implement these approaches.

Supplementary Materials: The following are available online at https: / www.mdpi.com/article/ 10.3390/su131910629/s1, Figure S1: NDR maps, current and 2050 scenarios for N; Figure S2: NDR maps, current and 2050 scenario for P; Table S1: Biophysical table. 
Author Contributions: Conceptualization, F.D.G. and L.G.; methodology, F.D.G., L.G., B.G. and S.A.L.; validation, F.D.G., L.G. and S.A.L.; data curation, F.D.G., L.G., B.G. and M.F.; writing-original draft preparation, F.D.G. and S.A.L.; writing-review and editing, F.D.G., S.A.L., B.G., L.G. and E.T.; funding acquisition, M.F. All authors have read and agreed to the published version of the manuscript.

Funding: This research was funded by the Italian Ministry of the Environment, under the project 'Piano di gestione delle Acque' and'Piano di gestione del Rischio di Alluvioni', project numbers ITN007_1DAO_001_M35 and ITN007_1DAO_002_M35, respectively.

Institutional Review Board Statement: Not applicable.

Informed Consent Statement: Not applicable.

Data Availability Statement: The raw data supporting the conclusions of this article will be made available by the authors without undue reservation.

Acknowledgments: The authors wish to thank Stefania Serra of the Autorità di Bacino Distrettuale delle Alpi Orientali and the Veneto Regional Agency for environmental protection (ARPAV) for providing hydrologic and hydrometeorological data used in this study. We also acknowledge the support of Paolo Cornelio of the Drainage Authority 'Consorzio di Bonifica Acque Risorgive' for the availability to share the costs of river restoration projects. A warm thanks to all citizen scientists in the project for their efforts, enthusiasm and fundamental data gathering.

Conflicts of Interest: The authors declare no conflict of interest.

\section{References}

1. Millenium Ecosystem Assessment. Ecosystems and Human Well-Being: General Synthesis; Island Press: Washington, DC, USA, 2005.

2. Costanza, R.; D’Arge, R.; De Groot, R.; Farber, S.; Grasso, M.; Hannon, B.; Limburg, K.; Naeem, S.; O’Neill, R.V.; Paruelo, J.M.; et al. The value of the world's ecosystem services and natural capital. Nature 1997, 387, 253-260. [CrossRef]

3. Foley, J.A.; DeFries, R.; Asner, G.; Barford, C.; Bonan, G.; Carpenter, S.R.; Chapin, F.S.; Coe, M.; Daily, G.C.; Gibbs, H.K.; et al. Global consequences of land use. Science 2005, 309, 570-574. [CrossRef] [PubMed]

4. Carpenter, S.R.; Mooney, H.A.; Agard, J.; Capistrano, D.; DeFries, R.S.; Díaz, S.; Dietz, T.; Duraiappah, A.K.; Oteng-Yeboah, A.; Pereira, H.M. Science for managing ecosystem services: Beyond the Millennium ecosystem assessment. Proc. Natl. Acad. Sci. USA 2009, 106, 1305-1312. [CrossRef] [PubMed]

5. Sharps, K.; Masante, D.; Thomas, A.; Jackson, B.; Redhead, J.; May, L.; Prosser, H.; Cosby, B.; Emmett, B.; Jones, L. Comparing strengths and weaknesses of three ecosystem services modelling tools in a diverse UK river catchment. Sci. Total Environ. 2017, 584-585, 118-130. [CrossRef] [PubMed]

6. Silvertown, J. A new dawn for citizen science. Trends Ecol. Evol. 2009, 24, 467-471. [CrossRef] [PubMed]

7. Bonter, D.; Cooper, C.B. Data validation in citizen science: A case study from Project FeederWatch. Front. Ecol. Environ. 2012, 10, 305-307. [CrossRef]

8. Bonney, R.; Shirk, J.L.; Phillips, T.B.; Wiggins, A.; Ballard, H.L.; Miller-Rushing, A.J.; Parrish, J.K. Next steps for citizen science. Science 2014, 343, 1436-1437. [CrossRef]

9. Dickinson, J.L.; Shirk, J.; Bonter, D.; Bonney, R.; Crain, R.; Martin, J.; Phillips, T.B.; Purcell, K. The current state of citizen science as a tool for ecological research and public engagement. Front. Ecol. Environ. 2012, 10, 291-297. [CrossRef]

10. Buytaert, W.; Zulkafli, Z.; Grainger, S.; Acosta, L.; Alemie, T.C.; Bastiaensen, J.; De Bièvre, B.; Bhusal, J.; Clark, J.; Dewulf, A.; et al. Citizen science in hydrology and water resources: Opportunities for knowledge generation, ecosystem service management, and sustainable development. Front. Earth Sci. 2014, 2. [CrossRef]

11. Fritz, S.; See, L.; Carlson, T.; Haklay, M.; Oliver, J.L.; Fraisl, D.; Mondardini, R.; Brocklehurst, M.; Shanley, L.A.; Schade, S.; et al. Citizen science and the United Nations sustainable development goals. Nat. Sustain. 2019, 2, 922-930. [CrossRef]

12. Njue, N.; Kroese, J.S.; Gräf, J.; Jacobs, S.; Weeser, B.; Breuer, L.; Rufino, M. Citizen science in hydrological monitoring and ecosystem services management: State of the art and future prospects. Sci. Total Environ. 2019, 693, 133531. [CrossRef]

13. Pandeya, B.; Buytaert, W.; Potter, C. Designing citizen science for water and ecosystem services management in data-poor regions: Challenges and opportunities. Curr. Res. Environ. Sustain. 2021, 3, 100059. [CrossRef]

14. Miller-Rushing, A.; Primack, R.B.; Bonney, R. The history of public participation in ecological research. Front. Ecol. Environ. 2012, 10, 285-290. [CrossRef]

15. Theobald, E.; Ettinger, A.; Burgess, H.; DeBey, L.; Schmidt, N.; Froehlich, H.; Wagner, C.; HilleRisLambers, J.; Tewksbury, J.; Harsch, M.; et al. Global change and local solutions: Tapping the unrealized potential of citizen science for biodiversity research. Biol. Conserv. 2014, 181, 236-244. [CrossRef]

16. McKinley, D.C.; Miller-Rushing, A.J.; Ballard, H.L.; Bonney, R.; Brown, H.; Cook-Patton, S.C.; Evans, D.M.; French, R.A.; Parrish, J.K.; Phillips, T.B.; et al. Citizen science can improve conservation science, natural resource management, and environmental protection. Biol. Conserv. 2017, 208, 15-28. [CrossRef]

17. Kullenberg, C.; Kasperowski, D. What is citizen science? A Scientometric Meta-Analysis. PLoS ONE 2016, 11, e0147152. [CrossRef] 
18. Schröter, M.; Kraemer, R.; Mantel, M.; Kabisch, N.; Hecker, S.; Richter, A.; Neumeier, V.; Bonn, A. Citizen science for assessing ecosystem services: Status, challenges and opportunities. Ecosyst. Serv. 2017, 28, 80-94. [CrossRef]

19. Raudsepp-Hearne, C.; Peterson, G.; Bennett, E.M. Ecosystem service bundles for analyzing tradeoffs in diverse landscapes. Proc. Natl. Acad. Sci. USA 2010, 107, 5242-5247. [CrossRef] [PubMed]

20. Schröter, M.; van der Zanden, E.M.; van Oudenhoven, A.P.E.; Remme, R.P.; Serna-Chavez, H.M.; de Groot, R.S.; Opdam, P. Ecosystem services as a contested concept: A synthesis of critique and counter-arguments. Conserv. Lett. 2014, 7, 514-523. [CrossRef]

21. Kabisch, N.; Qureshi, S.; Haase, D. Human-environment interactions in urban green spaces-A systematic review of contemporary issues and prospects for future research. Environ. Impact Assess. Rev. 2015, 50, 25-34. [CrossRef]

22. Bishop, I.J.; Warner, S.; Van Noordwijk, T.C.G.E.; Nyoni, F.C.; Loiselle, S. Citizen science monitoring for sustainable development goal indicator 6.3.2 in England and Zambia. Sustainability 2020, 12, 10271. [CrossRef]

23. Fraisl, D.; Campbell, J.; See, L.; Wehn, U.; Wardlaw, J.; Gold, M.; Moorthy, I.; Arias, R.; Piera, J.; Oliver, J.L.; et al. Mapping citizen science contributions to the UN sustainable development goals. Sustain. Sci. 2020, 15, 1735-1751. [CrossRef]

24. Keeler, B.L.; Polasky, S.; Brauman, K.; Johnson, K.A.; Finlay, J.; O’Neill, A.; Kovacs, K.; Dalzell, B. Linking water quality and well-being for improved assessment and valuation of ecosystem services. Proc. Natl. Acad. Sci. USA 2012, 109, 18619-18624. [CrossRef] [PubMed]

25. Pereda, O.; von Schiller, D.; García-Baquero, G.; Mor, J.-R.; Acuña, V.; Sabater, S.; Elosegi, A. Combined effects of urban pollution and hydrological stress on ecosystem functions of Mediterranean streams. Sci. Total Environ. 2020, 753, 141971. [CrossRef]

26. Vigerstol, K.L.; Aukema, J.E. A comparison of tools for modeling freshwater ecosystem services. J. Environ. Manag. 2011, 92, 2403-2409. [CrossRef]

27. Sharp, R.; Tallis, H.T.; Ricketts, T.; Guerry, A.D.; Wood, S.A.; Chaplin-Kramer, R.; Nelson, E.; Ennaanay, D.; Wolny, S.; Olwero, N.; et al. InVEST User Guide-InVEST + VERSION + Documentation. Available online: https://invest-userguide.readthedocs.io/en/3.5.0/ (accessed on 3 August 2021).

28. Garnier, J.; Billen, G.; Lassaletta, L.; Vigiak, O.; Nikolaidis, N.P.; Grizzetti, B. Hydromorphology of coastal zone and structure of watershed agro-food system are main determinants of coastal eutrophication. Environ. Res. Lett. 2021, 16, 023005. [CrossRef]

29. Lancelot, C.; Thieu, V.; Polard, A.; Garnier, J.; Billen, G.; Hecq, W.; Gypens, N. Cost assessment and ecological effectiveness of nutrient reduction options for mitigating Phaeocystis colony blooms in the Southern North Sea: An integrated modeling approach. Sci. Total Environ. 2011, 409, 2179-2191. [CrossRef] [PubMed]

30. Billen, G.; Garnier, J. The Phison River plume: Coastal eutrophication in response to changes in land use and water management in the watershed. Aquat. Microb. Ecol. 1997, 13, 3-17. [CrossRef]

31. McCrackin, M.L.; Muller-Karulis, B.; Gustafsson, B.G.; Howarth, R.W.; Humborg, C.; Svanbäck, A.; Swaney, D.P. A century of legacy phosphorus dynamics in a large drainage basin. Glob. Biogeochem. Cycles 2018, 32, 1107-1122. [CrossRef]

32. Turner, R.E.; Rabalais, N.N. Coastal eutrophication near the Mississippi river delta. Nature 1994, 368, 619-621. [CrossRef]

33. Turner, R.E.; Rabalais, N.N.; Justic', D.; Dortch, Q. Future aquatic nutrient limitations. Mar. Pollut. Bull. 2003, 46, 1032-1034. [CrossRef]

34. Cui, L.; Lu, X.; Dong, Y.; Cen, J.; Cao, R.; Pan, L.; Lu, S.; Ou, L. Relationship between phytoplankton community succession and environmental parameters in Qinhuangdao coastal areas, China: A region with recurrent brown tide outbreaks. Ecotoxicol. Environ. Saf. 2018, 159, 85-93. [CrossRef]

35. Liu, X.; Beusen, A.; Van Beek, L.P.; Mogollón, J.M.; Ran, X.; Bouwman, L. Exploring spatiotemporal changes of the Yangtze River (Changjiang) nitrogen and phosphorus sources, retention and export to the East China Sea and Yellow Sea. Water Res. 2018, 142, 246-255. [CrossRef] [PubMed]

36. Directive 2000/60/EC of the European Parliament and of the Council of 23 October 2000. Establishing a framework for Community action in the field of water policy. Off. J. Eur. Parliam. 2000, L327, 1-82.

37. European Council. Establishing common rules for direct support schemes for farmers under the common agricultural policy and establishing certain support schemes for farmers, amending Regulations (EC) No 1290/2005, (EC) No 247/2006, (EC) No 378/2007 and repealing Regulation. Eur. Rural Dev. Policy 2009, 73, 16-99.

38. Grizzetti, B.; Bouraoui, F.; Aloe, A. Changes of nitrogen and phosphorus loads to European seas. Glob. Chang. Biol. 2011, 18, 769-782. [CrossRef]

39. Romero, E.; Garnier, J.; Lassaletta, L.; Billen, G.; Le Gendre, R.; Riou, P.; Cugier, P. Large-scale patterns of river inputs in southwestern Europe: Seasonal and interannual variations and potential eutrophication effects at the coastal zone. Biodegradation 2012, 113, 481-505. [CrossRef]

40. Pistocchi, A.; Dorati, C.; Grizzetti, B.; Udias, A.; Vigiak, O.; Zanni, M. Water Quality in Europe: Effects of the Urban Wastewater Treatment Directive. A Retrospective and Scenario Analysis of Dir. 91/271/EEC; EUR 30003 EN; Publications Office of the European Union: Luxembourg, 2019; pp. 1-112. [CrossRef]

41. Rabalais, N.N.; Turner, R.E.; Scavia, D. Beyond Science into Policy: Gulf of Mexico Hypoxia and the Mississippi River. BioScience 2002, 52, 129-142. [CrossRef]

42. Turner, B.L.; Lambin, E.F.; Reenberg, A. The emergence of land change science for global environmental change and sustainability. Proc. Natl. Acad. Sci. USA 2007, 104, 20666-20671. [CrossRef] 
43. Shu, L.; Finlayson, B. Flood management on the lower Yellow River: Hydrological and geomorphological perspectives. Sediment. Geol. 1993, 85, 285-296. [CrossRef]

44. Wang, H.; Yang, Z.; Saito, Y.; Liu, P.; Sun, X. Interannual and seasonal variation of the Huanghe (Yellow River) water discharge over the past 50 years: Connections to impacts from ENSO events and dams. Glob. Planet. Chang. 2006, 50, 212-225. [CrossRef]

45. Ma, T.; Zhao, N.; Ni, Y.; Yi, J.; Wilson, J.P.; He, L.; Du, Y.; Pei, T.; Zhou, C.; Song, C.; et al. China's improving inland surface water quality since 2003. Sci. Adv. 2020, 6, eaau3798. [CrossRef] [PubMed]

46. Garnier, J.; Marescaux, A.; Guillon, S.; Vilmin, L.; Rocher, V.; Billen, G.; Thieu, V.; Silvestre, M.; Passy, P.; Raimonet, M.; et al. Ecological functioning of the Seine River: From Long-term modelling approaches to high-frequency data analysis. In Handbook of Environmental Chemistry; Science and Business Media Deutschland: Berlin, Germany, 2020; pp. 189-216. [CrossRef]

47. Torrecilla, N.J.; Galve, J.P.; Zaera, L.G.; Retamar, J.F.; Álvarez, A.N. Nutrient sources and dynamics in a mediterranean fluvial regime (Ebro River, NE Spain) and their implications for water management. J. Hydrol. 2005, 304, 166-182. [CrossRef]

48. Minaudo, C.; Meybeck, M.; Moatar, F.; Gassama, N.; Curie, F. Eutrophication mitigation in rivers: 30 years of trends in spatial and seasonal patterns of biogeochemistry of the Loire River (1980-2012). Biogeosciences 2015, 12, 2549-2563. [CrossRef]

49. Passy, P.; Le Gendre, R.; Garnier, J.; Cugier, P.; Callens, J.; Paris, F.; Billen, G.; Riou, P.; Romero, E. Eutrophication modelling chain for improved management strategies to prevent algal blooms in the Bay of Seine. Mar. Ecol. Prog. Ser. 2016, 543, 107-125. [CrossRef]

50. Desmit, X.; Thieu, V.; Billen, G.; Campuzano, F.; Dulière, V.; Garnier, J.; Lassaletta, L.; Ménesguen, A.; Neves, R.; Pinto, L.; et al. Reducing marine eutrophication may require a paradigmatic change. Sci. Total Environ. 2018, 635, 1444-1466. [CrossRef]

51. Garnier, J.; Riou, P.; Le Gendre, R.; Ramarson, A.; Billen, G.; Cugier, P.; Schapira, M.; Théry, S.; Thieu, V.; Ménesguen, A. Managing the agri-food system of watersheds to combat coastal eutrophication: A land-to-sea modelling approach to the French coastal English Channel. Geosciences 2019, 9, 441. [CrossRef]

52. Gumiero, B.; Cornelio, P.; Boz, B. Nitrogen removal by an irrigated wooded buffer area. Water Pract. Technol. 2011, 6, 1-2. [CrossRef]

53. Kuglerová, L.; Ågren, A.; Jansson, R.; Laudon, H. Towards optimizing riparian buffer zones: Ecological and biogeochemical implications for forest management. For. Ecol. Manag. 2014, 334, 74-84. [CrossRef]

54. Ou, Y.; Wang, X.; Wang, L.; Rousseau, A.N. Landscape influences on water quality in riparian buffer zone of drinking water source area, Northern China. Environ. Earth Sci. 2016, 75, 1-13. [CrossRef]

55. De Mello, K.; Randhir, T.O.; Valente, R.A.; Vettorazzi, C.A. Riparian restoration for protecting water quality in tropical agricultural watersheds. Ecol. Eng. 2017, 108, 514-524. [CrossRef]

56. Gumiero, B.; Boz, B. How to stop nitrogen leaking from a Cross compliant buffer strip? Ecol. Eng. 2017, 103, 446-454. [CrossRef]

57. Sabater, S.; Butturini, A.; Clement, J.-C.; Burt, T.; Dowrick, D.; Hefting, M.; Maître, V.; Pinay, G.; Postolache, C.; Rzepecki, M.; et al. Nitrogen removal by riparian buffers along a european climatic gradient: Patterns and factors of variation. Ecosystems 2003, 6 , 20-30. [CrossRef]

58. Sweeney, B.W.; Bott, T.L.; Jackson, J.K.; Kaplan, L.A.; Newbold, J.D.; Standley, L.J.; Hession, W.C.; Horwitz, R.J. Riparian deforestation, stream narrowing, and loss of stream ecosystem services. Proc. Natl. Acad. Sci. USA 2004, 101, 14132-14137. [CrossRef] [PubMed]

59. Schilling, K.E.; Jacobson, P. Effectiveness of natural riparian buffers to reduce subsurface nutrient losses to incised streams. Catena 2014, 114, 140-148. [CrossRef]

60. Loiselle, S.; Cunha, D.G.F.; Shupe, S.; Valiente, E.; Rocha, L.; Heasley, E.; Belmont, P.P.; Baruch, A. Micro and macroscale drivers of nutrient concentrations in urban streams in South, Central and North America. PLoS ONE 2016, 11, e0162684. [CrossRef]

61. Tanaka, M.O.; de Souza, A.L.T.; Moschini, L.E.; de Oliveira, A.K. Influence of watershed land use and riparian characteristics on biological indicators of stream water quality in southeastern Brazil. Agric. Ecosyst. Environ. 2016, 216, 333-339. [CrossRef]

62. Saalfeld, D.T.; Reutebuch, E.M.; Dickey, R.J.; Seesock, W.C.; Webber, C.; Bayne, D.R. Effects of landscape characteristics on water quality and fish assemblages in the Tallapoosa River Basin, Alabama. Southeast. Nat. 2012, 11, 239-252. [CrossRef]

63. Ding, S.; Zhang, Y.; Liu, B.; Kong, W.; Meng, W. Effects of riparian land use on water quality and fish communities in the headwater stream of the Taizi River in China. Front. Environ. Sci. Eng. 2013, 7, 699-708. [CrossRef]

64. Yang, H.; Wang, G.; Wang, L.; Zheng, B. Impact of land use changes on water quality in headwaters of the Three Gorges Reservoir. Environ. Sci. Pollut. Res. 2015, 23, 11448-11460. [CrossRef]

65. Zhang, X.; Liu, X.; Zhang, M.; Dahlgren, R.A.; Eitzel, M. A Review of vegetated buffers and a meta-analysis of their mitigation efficacy in reducing nonpoint source pollution. J. Environ. Qual. 2010, 39, 76-84. [CrossRef]

66. Yang, W.; Liu, Y.; Ou, C.; Gabor, S. Examining water quality effects of riparian wetland loss and restoration scenarios in a southern ontario watershed. J. Environ. Manag. 2016, 174, 26-34. [CrossRef] [PubMed]

67. Glibert, P.M.; Allen, J.I.; Artioli, Y.; Beusen, A.; Bouwman, L.; Harle, J.; Holmes, R.; Holt, J. Vulnerability of coastal ecosystems to changes in harmful algal bloom distribution in response to climate change: Projections based on model analysis. Glob. Chang. Biol. 2014, 20, 3845-3858. [CrossRef]

68. Wåhlström, I.; Höglund, A.; Almroth-Rosell, E.; MacKenzie, B.R.; Gröger, M.; Eilola, K.; Plikshs, M.; Andersson, H.C. Combined climate change and nutrient load impacts on future habitats and eutrophication indicators in a eutrophic coastal sea. Limnol. Oceanogr. 2020, 65, 2170-2187. [CrossRef] 
69. Whitehead, P.G.; Wilby, R.L.; Battarbee, R.W.; Kernan, M.; Wade, A. A review of the potential impacts of climate change on surface water quality. Hydrol. Sci. J. 2009, 54, 101-123. [CrossRef]

70. Garnier, J.; Ramarson, A.; Billen, G.; Théry, S.; Thiéry, D.; Thieu, V.; Minaudo, C.; Moatar, F. Nutrient inputs and hydrology together determine biogeochemical status of the Loire River (France): Current situation and possible future scenarios. Sci. Total Environ. 2018, 637-638, 609-624. [CrossRef] [PubMed]

71. Raimonet, M.; Thieu, V.; Silvestre, M.; Oudin, L.; Rabouille, C.; Vautard, R.; Garnier, J. Landward perspective of coastal eutrophication potential under future climate change: The Seine River case. Front. Mar. Sci. 2018, 5. [CrossRef]

72. Duan, H.; Ma, R.; Zhang, Y.; Loiselle, S.A. Are algal blooms occurring later in Lake Taihu? Climate local effects outcompete mitigation prevention. J. Plankton Res. 2014, 36, 866-871. [CrossRef]

73. Botter, G.; Basso, S.; Porporato, A.; Rodriguez-Iturbe, I.; Rinaldo, A. Natural streamflow regime alterations: Damming of the Piave river basin. Water Resour. Res. 2010, 46. [CrossRef]

74. Romero, E.; Le Gendre, R.; Garnier, J.; Billen, G.; Fisson, C.; Silvestre, M.; Riou, P. Long-term water quality in the lower Seine: Lessons learned over 4 decades of monitoring. Environ. Sci. Policy 2016, 58, 141-154. [CrossRef]

75. ISPRA. DEM 20m-Italy. Available online: http://www.sinanet.isprambiente.it/it/sia-ispra/download-mais/dem20/view (accessed on 3 August 2021).

76. ISPRA. Corine Land Cover 2018 IV livello I Uso, Copertura e Consumo di Suolo. Available online: http:/ / groupware.sinanet. isprambiente.it/uso-copertura-e-consumo-di-suolo/library/copertura-del-suolo/corine-land-cover/corine-land-cover-2018 -iv-livello (accessed on 3 August 2021).

77. Dezsi, Ş.; Mîndrescu, M.; Petrea, D.; Rai, P.K.; Hamann, A.; Nistor, M.-M. High-resolution projections of evapotranspiration and water availability for Europe under climate change. Int. J. Clim. 2018, 38, 3832-3841. [CrossRef]

78. ARPAV. Bacini Idrografici del Piano di Tutela delle Acque-Geomap ARPAV. Available online: http://geomap.arpa.veneto.it/ layers/geonode\%3Abacinipta (accessed on 3 August 2021).

79. ARPAV. Corpi idrici fluviali (Progetti di Piano, 2020)—Geomap ARPAV. Available online: http://geomap.arpa.veneto.it/layers/ geonode\%3Acorpi_idrici_fluviali (accessed on 3 August 2021).

80. Borselli, L.; Cassi, P.; Torri, D. Prolegomena to sediment and flow connectivity in the landscape: A GIS and field numerical assessment. Catena 2008, 75, 268-277. [CrossRef]

81. ARPAV. Carichi di Azoto Agricolo, da Allevamento e da Fertilizzanti-Geomap ARPAV. Available online: http://geomap.arpa. veneto.it/layers/geonode\%3Acarichi_azotoagricolo (accessed on 3 August 2021).

82. ARPAV. Carta del Rischio di Percolazione Dell'azoto-Geomap ARPAV. Available online: http://geomap.arpa.veneto.it/maps/270 (accessed on 3 August 2021).

83. ARPAV; Giandon, P.; Carta Della Capacità Protettiva E Del Rischio Di Percolazione Dell'azoto Dei Suoli Della Pianura Veneta. Report 2016. Available online: https://www.arpa.veneto.it/temi-ambientali/suolo/file-e-allegati/documenti/minacce-didegradazione/Cap_prot_relazione_2016.pdf (accessed on 3 August 2021).

84. ARPAV. Capacità Protettiva dei Suoli-Geomap ARPAV. Available online: http://geomap.arpa.veneto.it/layers/geonode\% 3Acaprotsuoli (accessed on 3 August 2021).

85. ARPAV. Acque Sotterranee-Concentrazione di Nitrati. Available online: https://www.arpa.veneto.it/dati-ambientali/opendata/idrosfera/acque-sotterranee/acque-sotterranee-concentrazione-di-nitrati (accessed on 3 August 2021).

86. Pärn, J.; Pinay, G.; Mander, Ü. Indicators of nutrients transport from agricultural catchments under temperate climate: A review. Ecol. Indic. 2012, 22, 4-15. [CrossRef]

87. Mayer, P.M.; Reynolds, S.K.; McCutchen, M.D.; Canfield, T.J. Meta-analysis of nitrogen removal in riparian buffers. J. Environ. Qual. 2007, 36, 1172-1180. [CrossRef]

88. FreshWater Watch Methods Manual. Available online: https://freshwaterwatch.thewaterhub.org/sites/default/files/fwwmethods-manual.pdf (accessed on 3 August 2021).

89. Scott, A.B.; Frost, P.C. Monitoring water quality in Toronto's urban stormwater ponds: Assessing participation rates and data quality of water sampling by citizen scientists in the FreshWater Watch. Sci. Total Environ. 2017, 592, 738-744. [CrossRef] [PubMed]

90. Thornhill, I.; Chautard, A.; Loiselle, S. Monitoring biological and chemical trends in temperate still waters using citizen science. Water 2018, 10, 839. [CrossRef]

91. Strickland, J.D.H.; Parsons, T.R. A practical handbook of seawater analysis. Bull. Fish. Res. Board Can. $1972,167,405$.

92. Law, A.T.; Adeloju, S.B. Progress and recent advances in phosphate sensors: A review. Talanta 2013, 114, 191-203. [CrossRef]

93. ARPAV. Meteo \& Clim-From 1994 to 2020. Available online: https:/ / www.arpa.veneto.it/dati-ambientali/open-data/clima (accessed on 3 August 2021).

94. NOAA. NCEP/NCAR Reanalysis 1: NOAA Physical Sciences Laboratory. Available online: https://psl.noaa.gov/data/gridded/ data.ncep.reanalysis.html (accessed on 3 August 2021). 
95. Wanner, H.; Brönnimann, S.; Casty, C.; Gyalistras, D.; Luterbacher, J.; Schmutz, C.; Stephenson, D.B.; Xoplaki, E. North Atlantic Oscillation-Concepts and Studies. Surv. Geophys. 2001, 22, 321-381. [CrossRef]

96. Hurrell, J.W.; Kushnir, Y.; Ottersen, G.; Visbeck, M. An overview of the North Atlantic Oscillation. Geophys. Monogr. Ser. 2003, 134, 1-35. [CrossRef]

97. Daly, C.; Halbleib, M.; Smith, J.I.; Gibson, W.P.; Doggett, M.K.; Taylor, G.H.; Curtis, J.; Pasteris, P.P. Physiographically sensitive mapping of climatological temperature and precipitation across the conterminous United States. Int. J. Clim. 2008, 28, 2031-2064. [CrossRef]

98. Copernicus. Coperenicus (clc2018). Available online: https://land.copernicus.eu/pan-european/corine-land-cover/clc2018 (accessed on 13 April 2019).

99. Picco, L.; Comiti, F.; Mao, L.; Tonon, A.; Lenzi, M. Medium and short term riparian vegetation, island and channel evolution in response to human pressure in a regulated gravel bed river (Piave River, Italy). Catena 2017, 149, 760-769. [CrossRef]

100. Consorzio di Bonifica Acque Risorgive. Interventi Riqualificazione. Available online: https://www.acquerisorgive.it/ambiente/ documentazione/interventi-riqualificazione/ (accessed on 3 August 2021).

101. Jiang, F.; Beck, M.B.; Cummings, R.G.; Rowles, K.; Russell, D. Estimation of Costs Of phosphorus removal in wastewater treatment facilities: Construction de novo. Water Policy Work. Pap. 2004, 2004, 28. Available online: http:// citeseerx.ist.psu.edu/viewdoc/ download?doi=10.1.1.553.4588\&rep=rep1\&type=pdf (accessed on 3 August 2021).

102. Strokal, M.; Kroeze, C.; Wang, M.; Bai, Z.; Ma, L. The MARINA model (Model to Assess River Inputs of Nutrients to seAs): Model description and results for China. Sci. Total Environ. 2016, 562, 869-888. [CrossRef]

103. Bashar, R.; Gungor, K.; Karthikeyan, K.; Barak, P. Cost effectiveness of phosphorus removal processes in municipal wastewater treatment. Chemosphere 2018, 197, 280-290. [CrossRef]

104. Gratziou, M.; Chrisochoidou, P. Cost analysis of wastewater nitrogen removal in Greece. Fresenius Environ. Bull. 2013, 22, 2117-2123.

105. Bladé, I.; Liebmann, B.; Fortuny, D.; van Oldenborgh, G.J. Observed and simulated impacts of the summer NAO in Europe: Implications for projected drying in the Mediterranean region. Clim. Dyn. 2011, 39, 709-727. [CrossRef]

106. Meehl, G.A.; Covey, C.; Delworth, T.; Latif, M.; McAvaney, B.; Mitchell, F.B.; Stouffer, R.J.; Taylor, K.E. The WCRP CMIP3 multimodel dataset: A new era in climate change research. Bull. Am. Meteorol. Soc. 2007, 88, 1383-1394. [CrossRef]

107. Baruffi, F.; Cisotto, A.; Cimolino, A.; Ferri, M.; Monego, M.; Norbiato, D.; Cappelletto, M.; Bisaglia, M.; Pretner, A.; Galli, A.; et al. Climate change impact assessment on Veneto and Friuli plain groundwater. Part I: An integrated modeling approach for hazard scenario construction. Sci. Total Environ. 2012, 440, 154-166. [CrossRef] [PubMed]

108. Stocker, T.F.; Qin, D.; Plattner, G.K.; Tignor, M.; Allen, S.K.; Boschung, J.; Nauels, A.; Xia, Y.; Bex, V.; Midgley, P.M. Ipcc, 2013: Climate change 2013: The physical science basis. In Contribution of Working Group I to the Fifth Assessment Report of the Intergovernmental Panel on Climate Change; Cambridge University Press: Cambridge, UK, 2013; Volume 1535, Available online: https:/ / www.eea.europa.eu/data-and-maps/indicators/global-and-european-temperature-9/ipcc-2013-summaryfor-policymakers-2013 (accessed on 3 August 2021).

109. ARPAV. La Rete Idrometrica e le Portate. Available online: https://www.arpa.veneto.it/temi-ambientali/idrologia/file-eallegati/rapporti-e-documenti/idrologia-regionale/idrologia-regionale-la-rete-idrometrica (accessed on 3 August 2021).

110. Redhead, J.W.; May, L.; Oliver, T.H.; Hamel, P.; Sharp, R.; Bullock, J.M. National scale evaluation of the InVEST nutrient retention model in the United Kingdom. Sci. Total Environ. 2018, 610, 666-677. [CrossRef]

111. Seddon, N.; Chausson, A.; Berry, P.; Girardin, C.A.J.; Smith, A.; Turner, B. Understanding the value and limits of nature-based solutions to climate change and other global challenges. Philos. Trans. R. Soc. B Biol. Sci. 2020, 375, 20190120. [CrossRef] [PubMed]

112. Lasanta, T.; Arnáez, J.; Pascual, N.; Ruiz, P.; Errea, M.; Lana-Renault, N. Space-time process and drivers of land abandonment in Europe. Catena 2017, 149, 810-823. [CrossRef]

113. Malavasi, M.; Carranza, M.L.; Moravec, D.; Cutini, M. Reforestation dynamics after land abandonment: A trajectory analysis in Mediterranean mountain landscapes. Reg. Environ. Chang. 2018, 18, 2459-2469. [CrossRef]

114. Rocchini, D.; Perry, G.L.; Salerno, M.; Maccherini, S.; Chiarucci, A. Landscape change and the dynamics of open formations in a natural reserve. Landsc. Urban Plan. 2006, 77, 167-177. [CrossRef]

115. Wade, A.J.; Butterfield, D.; Whitehead, P. Towards an improved understanding of the nitrate dynamics in lowland, permeable river-systems: Applications of INCA-N. J. Hydrol. 2006, 330, 185-203. [CrossRef]

116. Tasser, E.; Mader, M.; Tappeiner, U. Effects of land use in alpine grasslands on the probability of landslides. Basic Appl. Ecol. 2003, 4, 271-280. [CrossRef]

117. Seeber, J.; Seeber, G. Effects of land-use changes on humus forms on alpine pastureland (Central Alps, Tyrol). Geoderma 2005, 124, 215-222. [CrossRef]

118. Fox, G.A.; Purvis, R.A.; Penn, C.J. Streambanks: A net source of sediment and phosphorus to streams and rivers. J. Environ. Manag. 2016, 181, 602-614. [CrossRef]

119. Cozzi, S.; Ibáñez, C.; Lazar, L.; Raimbault, P.; Giani, M. Flow regime and nutrient-loading trends from the largest South European Watersheds: Implications for the productivity of Mediterranean and Black Sea's coastal areas. Water 2018, 11, 1. [CrossRef]

120. Jabłońska, E.; Wiśniewska, M.; Marcinkowski, P.; Grygoruk, M.; Walton, C.R.; Zak, D.; Hoffmann, C.C.; Larsen, S.E.; Trepel, M.; Kotowski, W. Catchment-scale analysis reveals high cost-effectiveness of wetland buffer zones as a remedy to non-point nutrient pollution in North-Eastern Poland. Water 2020, 12, 629. [CrossRef] 
121. Spillman, C.; Imberger, J.; Hamilton, D.; Hipsey, M.; Romero, J. Modelling the effects of Po River discharge, internal nutrient cycling and hydrodynamics on biogeochemistry of the Northern Adriatic Sea. J. Mar. Syst. 2007, 68, 167-200. [CrossRef]

122. IPCC. Climate Change and Land: An IPCC Special Report on Climate Change, Desertification, Land Degradation, Sustainable land Management, Food Security, and Greenhouse Gas Fluxes in Terrestrial Ecosystems. Available online: https://scholar. googleusercontent.com/scholar?q=cache:52WbLPsPDU4J:scholar.google.com/+IPCC+Climate+Change+and+Land+Report+ (accessed on 3 August 2021) 